\title{
Market Risk and Stock Return of Listed Financial Service Firms in Nigeria
}

\author{
Isuwa Dauda, Agbi Eniola Samuel,Okpanachi Joshua,and Suleiman Tauheed \\ Department of Accounting, Faculty of Management Sciences, \\ Nigerian Defence Academy, Kaduna, Nigeria
}

\begin{abstract}
The trading financial instruments in the capital market by Financial Service Firms (FSF) have generated return arising from changes in the prices of stock which exposed the firms to market risk. An effective market risk decision remains significant to determining stock return level realized from the volume and value of stock traded. This study examines the effect of market risk on stock return of listed FSF in Nigeria. The population of this study consists of fifty-six (56) financial service firms listed in the Nigerian Stock Exchange Market. In arriving at the sample size of twenty-nine (29) firms the purposive sampling technique and filtering criteria were employed. Data were sourced secondarily from the audited annual report of financial service firms, Nigeria Stock Exchange fact book, and other relevant financial service firms' websites for period of twelve (12) years (2007-2018). Panel multiple regression technique of data analysis was applied using the ordinary least square estimator. The findings of the study revealed that book to market ratio as a proxy of market risk was insignificantly negative on stock return during the period under review. Net interest margin as a proxy of market risk revealed a significant positive effect on stock return during the period of review. Also, the study revealed that control variables of firm size, leverage had significant positive effects on stock return, though; the effect of monetary policy rate was positive but insignificant on stock return. The study concluded that a higher book to market ratio would reduce stock return and to a larger extent the reduction in stock return may not be affected significantly. It also concluded that a higher net interest margin would result to a higher stock return and vice versa. The study recommended that decisionmakers and portfolio managers of financial service firms should employ appropriate risk strategies through derivatives, forwards, futures, swaps, options that can mitigate market risk in order to optimize return.
\end{abstract}

Keywords: Financial Services Firms, Stock Returns, Market Risk, Firms Specific Risk factors, Nigerian Stock exchange.

DOI: $10.7176 / \mathrm{EJBM} / 13-8-10$

Publication date: April $30^{\text {th }} 2021$

\section{Introduction}

There has been increasing research regarding stock return as a vital reason for investing in firms. Invariably, stock return has remained significant to an investor as the main objective of investing in a firm's common stock. Stock return can be in the form of capital appreciation or depreciation and dividend received. Stock return in the form of capital appreciation or depreciation entails a certain rise or fall in the value of stock based on the rise or fall in share market price. Stock prices are significant metrics to stock return which are determined by the forces of demand and supply and influenced by firm specific factors such as size, leverage, monetary policy rate that explain the behavior of expected stock return. Stock return is affected by variability of stock price changes which could increase or decrease information during a period of time and the dividend to be paid.

Investors are usually concerned about stock return because fluctuations in stock prices which affect the predictability of stock return appear to be influenced by information about the firm or market in totality. Karolyi (2001) posited how the existence of excessive volatility, or "noise," undermines the usefulness of stock prices as a "signal" about the true intrinsic value of a firm; a concept that is core to the paradigm of the informational efficiency of markets. It is true to say that institutional investors are typically interested in minimizing risks associated with their investments, while at the same time attempting to maximize investment returns. Risk arises out of uncertainty. It is the probability of a deviation from an anticipated outcome. The development of financial theories like arbitrage pricing, modern portfolio, capital asset pricing model, and efficient market hypothesis has laid emphasis on risk as a significant predictor of stock return. These theories explain the concern of financial market players over a given level of risk and upon which they adjust their returns expectations. The arbitrage pricing theory (APT) describes that stock return is affected by a series of risk ranging from firm and macro risk factors.

According to Ross (1976), on his Arbitrage Pricing Theory (APT) suggested that return on stock and the increasing importance played by market risk are subject to macroeconomic variables like monetary policy rate or interest rate, inflation, exchange rate, gross domestic product, unemployment rate, domestic savings, stock market liquidity. The activities in a stock market generate returns that give rise to market risk. Market risk is the probability that an overall market will decline by reducing the value of a firm's investment regardless of firm specific characteristics like growth, revenues, earnings, management, and capital structure. In other words, market risk 
involves the potential loss of value in assets and liabilities due to changes in market variables like interest rate, foreign exchange rates, commodity prices and equity. Stock market return is systematically affected by the type of information randomly received. According to Gupta and Modise (2013), such influential information involves interest rate.

Interest rate is seen as the cost of capital or an investment. In other words, it is a fixed value of fund received as return from an investment in stock which is expressed in percentage. Changes in interest rate on long term or short term basis is believed to have effect on stock return which is influenced by a change in monetary policy rate or discount rate of a central or reserve bank. According to Bomfim (2001), daily volatility in asset prices could be affected by announcement in change on monetary policy rate. A High interest rate can increase costs for firms across a wide range of measures and lead to lower net interest margin which subsequently lower stock prices. However, gradually rising interest rates might actually be beneficial for the stock market as they may reflect positive trends. Net interest margin basically measures the difference between interests paid and interests received. In other words, it's a measure of return on a firm's investments relative to its interest expenses. The net interest margin of financial firms is directly related to interest rates in the economy. When market interest rates fall, the funding costs of financial service firms fall relative to their interest income, and ultimately, net interest income increases.

Shafana et al. (2013) stated that return from stock is subjected to variations owing to the movement of stock price, which depends on various factors that could be firm specific such as book to market ratio, firm size, leverage and these factors explain the behavior of expected stock returns. The book-to-market ratio assesses a firm's value by comparing book value to market value. The book value is defined by the common shareholder equity, while the market value is defined by market capitalization. The influence of firm size on stock returns remains an empirically contentious issue, previous studies provide varying evidence on the stock returns earned by firms and with small firms earning higher stock return than large firms. However, size and leverage remain a significant factor that explains the behavior of expected stock return. Leverage is commonly described as the use of borrowed funds to create an investment and expect return on that investment. A firm with debt and equity outstanding typically becomes more highly leveraged when the value of the firm falls and vice versa.

The effect of the subprime crisis in 2008 caused huge losses and uncertainties on stock returns and other portfolio investments in financial service firms. In Nigeria, the total market capitalization of the Stock market experienced a decrease from $74.7 \%$ in 2007 to $45.8 \%$ in 2008 (Onuoha \& Nwaiwu, 2016). In addition, the equity market value dropped by a total of $\$ 2.354$ billion between 2014 and 2015 . The performance of the Nigerian equities market in 2017 was mixed as the weak sentiment which had persisted since June 2014 lingered into quarter 1 of 2017 (Afrinvest, 2017).

Empirical studies have been conducted on market risk and stock return as few studies have considered firm specific variables such as stock beta, net interest margin, book-to-market ratio to proxy market risk (Handayani, Farlian \& Ardian,2019; Osamwonyi \& Asein,2012; Morelli, 2007; Badawi, 2017; Muriithi, Muturi \& Waweru, 2016; Nurazi \& Usman, 2016; Fama \& French, 1992; Kassi, Rathnayake, Louembe \& Ding, 2019; Agbam, Anyamaobi \& Udo, 2018; Gautam, 2017; Akwe, Garba \& Dang, 2018). Other studies considered macro-economic variables like foreign exchange rate, inflation, equity pricing. These studies include Mwaurah, Muturi and Waititu (2017), Fahmi, Geetha and Mohidin (2017). The use of different proxies ranging from firm specific to macroeconomic variables to measure market risk have provided different research results and reactions. Also, the results from these studies must have been predicated on stock market indices that vary across countries. Nevertheless, the scope of these studies might influence the different findings obtained as a result of significant events that have created market risk in the stock market as well as return on stock. Based on domain differences and variables measurement, country specific, and scope of prior studies, effect of market risk on stock return of listed financial service firms in Nigeria is considered for examined. Based on the study objective the following hypotheses in null form were formulated and tested.

$\mathrm{Ho}_{1}$ : Book-to-market ratio has no significant effect on stock return of listed financial service firms in Nigeria.

$\mathrm{H}_{02}$ : Net Interest Margin has no significant effect on stock return of listed financial service firms in Nigeria.

This study which covered the period of twelve (12) years from 2007 to 2018 with emphasis on listed financial service firms in Nigeria was based on the significant events that occurred in the financial industry ranging from the global financial crisis in 2008 as well as the Nigerian economic recession in 2014 . The study would be relevant to investors, policy makers, and regulatory agencies in understanding the link between market risk and stock return. In addition, this study would be relevant to the academic circle by adding to existing knowledge. Other parts of the research are structured into literature review, methodology, results and discussions, and conclusion and recommendations.

\section{Literature Review}

In order to examine the effect of market risk on stock return, conceptual framework defining the variables of the study, relevant theories, and empirical studies were discussed. The conceptual framework for the study as depicted 
in Figure 1 explained market risk (MKR), book-to-market ratio (BMR), net interest margin (NIM), and stock return (STR).

\section{Independent Variable Market Risk}

Control Variable

Dependent Variable

Stock Returns

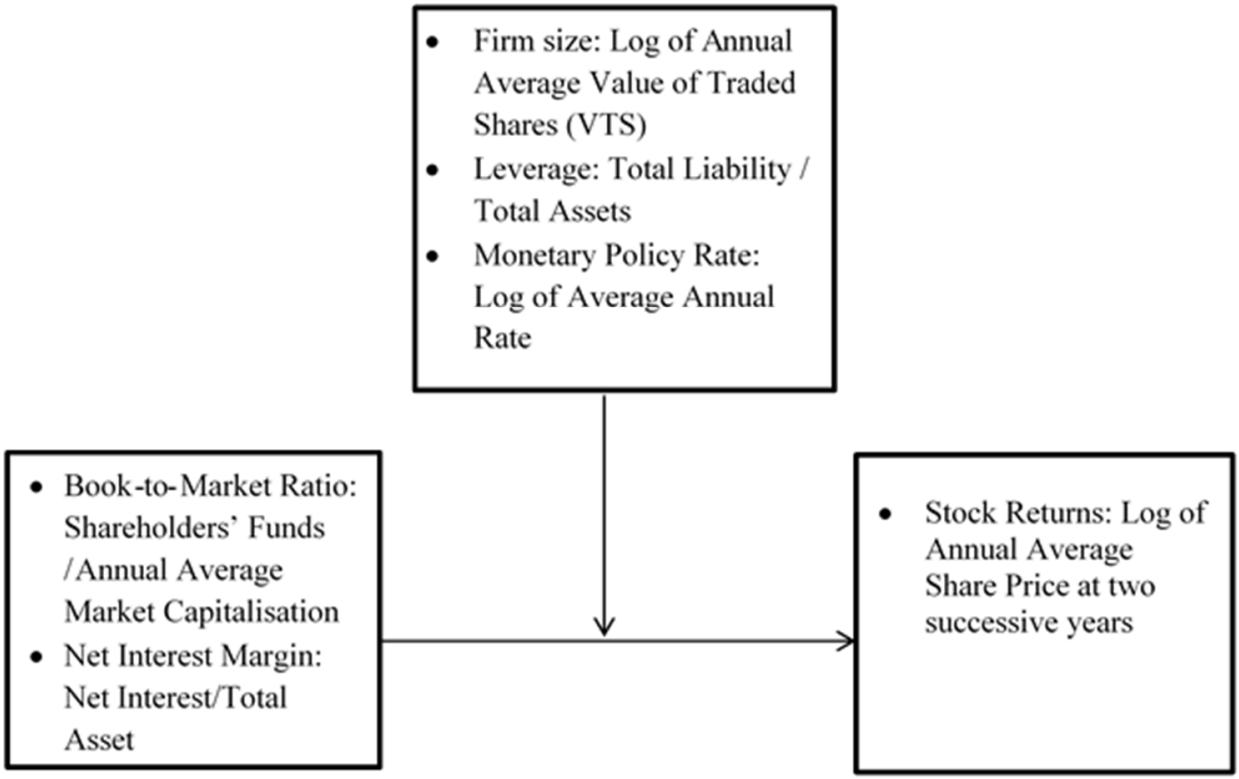

Figure 1

Source: Field Work (2020)

Market risk involves loss resulting from changes in the value of assets and liabilities (including off-balance sheet assets and liabilities) due to fluctuations in risk factors such as interest rates, foreign exchange rates and stock prices (Sukcharoensin, 2013). In other words, market risk is the probability that the value of an investment will be affected due to changes in market factors such as interest rate, foreign exchange rate, and inflation. The relationship between market risk and stock return is a reflection of a firm's asset valuation and investment as the return on stock rises with risk.

Empirical studies have provided measures or indicators of market risk to include firm specific variables of book-to-market ratio which is defined as net total assets or shareholders fund to market capitalization (Kassi, Rathnayake, Louembe \& Ding, 2019; Chen et al.,2010; Agbam, Anyamaobi \& Okon, 2018; Gautam, 2017; Morelli, 2007; Akwe, Garba \& Dang 2018); net interest margin defined as net interest income to total assets or average earning asset (Chaudhry et al., 2008; Badawi, 2017; Muriithi, Muturi \& Waweru, 2016; Murazi \& Usman, 2016). Other empirical measures of market risk include interest rate risk defined in terms of treasury bill or commercial paper rates (Belke \& Poliet, 2004; Mwaurah, 2019), monetary policy rate (Okpara, 2010); foreign exchange risk defined as percentage change in a country's currency rate to a base rate (Mwaurah, 2019); inflation rate defined change in general price level of goods and services on a year-to-year basis (Alagided \& Panagiotidis, 2006; Daferighe \& Aje, 2009); monetary policy rate defined as the interest rate issued by a central or reserve bank of a country (Abbass, Song, Shah \& Aziz, 2019).

The book-to-market ratio (BMR) is a measure used to compare the book value to market value of a firm. The accounting or book value represents net total assets or shareholders fund while market capitalization estimates the market value. A ratio of less than one or more than one denotes an overvalued or undervalued firm respectively. The study of Fama and French (1992) and Chen et al. (2005) both affirmed that book-to-market ratio and firm size are vital market risk factors that predict stock return as well as critical in investment decisions.

According to English (2002), changes in market interest rates impact on the economic value of a firm's assets, liabilities, and off-balance sheet position. Interest rate represents cost of investment or reward for investment. Interest rate remains a determinant of net interest margin (NIM) because when market interest rate increases the firm's funding costs rapidly increases in relation to interest income and consequently net interest margin increases and vice versa. NIM measures how successful a firm is in terms of net return on investment. Empirical studies have provided measures of NIM to include difference between total interest income and total interest paid to total assets (Chaudhry et al., 2000; Reichert \& Shyu,2003), and net interest to average earning assets (Badawi, 2017).

Firm size is seen in terms of the value of its financial assets. In other words, it could be seen in terms of the capacity to absorb risk supported by availability of liquid funds. Larger firms are usually more diversified, hence, 
associated with more returns and less risk (Serrasqueiro \& Nunes, 2008; Yang \& Chen, 2009). In addition, large firms have the economies of scale to attract more investment and by extension increase the firm's market share price. Firm size has been measured in different ways to include volume of traded shares (Zaigham,Wang \& Ali, 2019), value of total assets, number of employees, and market capitalization (Leledakis, Davidson \& Smith, 2004). The study of Llorente, Michaely, Saar and Wang (2002) posited that average daily number of shares traded increase with firm size.

Leverage indicates the proportion of a firm's assets that is financed by debt against equity (Gautam, 2017). In other words, it provides a measure of overall indebtedness of a firm. Highly leveraged firms follow the maxim that a high risk is associated with greater probability of higher return. In addition, the risk-return trade-off states that the potential return rises with an increase in risk. The relationship between leverage and stock return can be pinned to Modigliani \& Miller theorem published in 1958 which proposed that future stocks return should increase with the amount of leverage. Their reasoning is centered on the position that the higher the proportion of debt in a firm, the higher the risk of owning the firm's stock and the more should investors be compensated in terms of returns. Demirovic (2013) identified four indicators of leverage measurement which include total liabilities to total assets, total liabilities to shareholders equity, total debt to total assets, and total debt to shareholders equity.

Changes in interest rate are induced by monetary policy rate (MPR). MPR is an interest rate set by a monetary authority in order to influence the evolution of the main monetary variables in an economy (consumer prices, exchange rate, credit expansion). In other words, it determines the various interest rates in the economy such as lending rate, discount rate, and repurchase rate. More often than not, a central bank of a country use MPR to perform contractive or expansive monetary policy that consequently affects fluctuations in stock return through stock prices. Ioannidis and Kontonikas (2008) argued that stock market returns tend to be higher during periods of expansion and lower during contraction.

Stock return is the gains that an investor generates as dividend and increase or decrease in stock price (capital gains/losses). Financial firms see return as the fundamental reason for investing. One common way of generating stock return is through trading in the secondary market where an investor buys a stock at a lower price and sell at a higher price (Idris \& Bala, 2015). It is imperative to affirm that the relative growth or decrease in a stock share price has a corresponding impact on the dividend that a firm pays. Empirical studies like Isa and Yakob (2013) and Gautam (2017) have shown that stock prices are important metrics of stock return.

Empirically, studies that focused on market risk have been influenced by pressures on firms' assets and liabilities positions as well as extreme events that caused financial crises and these events have impacted on stock return. Morelli (2007) empirically examined the explanatory strength of beta, size and book-to-market ratio in explaining cross-sectional stock returns of 300 randomly selected United Kingdom (UK) stocks from 1980 to 2000. Monthly adjusted stock data were collected from the London Share Price Database (LSPD). The results of the study revealed that beta and firm size were not significant risk factors in explaining stock returns over the sample period. The book-to-market ratio was found to be significantly positive. The result confirmed book-to-market ratio as a major risk factor explaining stock returns.

The study of Nurazi and Usman (2016) examined the effect of CAMELS (capital adequacy, asset quality, management quality, earnings, liquidity, sensitivity to market risk) and macroeconomics variables (interest rate, exchange rate, and inflation rate) on stock return of 16 banks in Indonesia Stock Exchange from 2002 to 2011. Pooled Least Squares Model (PLSM) was used in analyzing the data. The result revealed that NIM as a proxy of management quality is insignificantly negative on stock return while interest rate as a macroeconomic variable revealed an insignificant negative effect on stock return.

Gautam (2017) examined the impact of firm specific variables on stock price volatility and stock return of Nepalese commercials banks from 2008 to 2016. This study considered bank specific variables of leverage ratio, market capitalization, asset growth, earning price ratio, dividend yield, and book-to-market ratio as explanatory variables to stock price volatility and stock return as dependent variables. The study employed multiple regression model in analyzing data. The study revealed that book-to-market ratio has a significant negative impact on stock returns. However, the study revealed that leverage and market capitalization had an insignificant positive effect on stock return.

The study of Handayani, Farlian and Ardian (2019) examined the influence of firm size and market risk on stock return of Indonesian high reliable 45 most liquid (LQ45) listed companies from 2015 to 2017. Firm size and market risk (market beta) were employed as independent variables while stock return was used as the dependent variable. The study employed a multiple regression model to analyze panel data. The results of the study revealed that market risk has an insignificant positive effect on stock return while firm size has a significant positive effect on the stock return.

Iskandar (2020) carried out a study to examine the effects of capital adequacy ratio, loan to deposit ratios, and net interest margin on stock return of commercial banks in Indonesia from 2016 to 2018 . The study considered 15 banks as sample banks. The study employed the multiple regression model to analyze data obtained. The results showed that net interest margin, capital adequacy ratio, and loan to deposit ratio significantly influence the stock 
return of banks shares positively.

The study of Kassi, Rathnayake, Louembe and Ding (2019) examined the effect of market risk on the financial performance of 31 non-financial companies listed on the Casablanca Stock Exchange (CSE) from 2000 to 2016. The study used financial leverage, book-to-market ratio, and gearing ratio as indicators of market risk while return on assets, return on equity and profit margin were representatives of financial performance. The pooled ordinary least square model was used in analyzing data. The finding revealed that book-to-market ratio and financial leverage had a significant negative effect on financial performance. However, gearing ratio revealed a significant positive effect.

Mwaurah, Muturi and Waititu (2017) carried out a study on the influence of financial risk on stock returns on 9 listed banks in Kenya stock market from 2006 to 2015. The study used market risk, credit risk, liquidity risk, and capital risk as independent variables while stock return was used as a dependent variable. Market risk was proxy by rate of change of exchange rate while bank size was used as a control variable. The study adopted a multivariate generalized least square regression model for analysis. The findings of their study revealed that market risk has a significant positive effect on stock return. In a related vein, Muriithi et al. (2016) analyzed the impact of market risk on the financial performance of 43 commercial banks in Kenya from 2005 to 2014. The independent variable of market risk was measured by degree of financial leverage, foreign exchange exposure risk, and interest rate risk (log of net interest margin) while financial performance was proxy by return on equity. The study used a fixed effect model and generalized method of moments to analyse data. Their finding revealed that degree of financial leverage, foreign exchange exposure risk, and interest rate risk (log of net interest margin) had significant negative effect on financial performance.

Osamwonyi and Asein (2012) conducted a study on the effect of market risk on security returns with evidence from the Nigerian Capital Market from 2001 to 2005. The independent variable of market risk was proxy by beta while security returns were proxied by Treasury bill and All Share Market Index. The study employed the Capital Asset Pricing Model (CAPM) to analyse data. Their findings revealed a significant positive effect of market risk on security returns. According to Fama and French (1992) three factor model that consist of beta, size and value explain portfolio market return better than beta as a factor model in CAMP. This is corroborated in the study of Daniel et al. (2002) where they posited that stock betas has little or no ability in explaining the behavior of expected stock returns but firm size and book-to-market ratio play significant role in explaining the behavior of expected stock returns.

The study of Agbam, Anyamaobi and Udo (2018) investigated the significance of beta, firm size and bookto-market ratio in explaining variations in stock returns of 59 randomly selected listed firms on the Nigerian Capital Market from 2012 to 2015. The study employed the Fama and French (1992) multifactor model which explained three risk factors namely market risk, size risk, and value risk. The classical ordinary least square was employed to test the multifactor model. Their findings revealed that the effect of firm size was significantly positive on stock returns while book-to-market ratio was insignificantly negative on stock returns.

The study of Akwe, Garba and Dang (2018) examined the effect of firm level attributes on stock returns of top twenty-five most capitalized quoted equity firms in Nigeria from 2007 to 2016. Firm size, book-to-market ratio, and price to earnings ratio were representatives of independent variables while stock return was considered as dependent variable. Analysis of data was carried out using multiple regressions. Their findings revealed that the ratio of book-to-market ratio and price to earnings ratio had a significant and insignificant positive effect on stock returns respectively while firm size has an insignificant negative effect on stock returns.

Some studies have used leverage and monetary policy rate to examine their effect on stock return. The study of Uwuigbe, Olowe, Olusegun, and Godswill (2012) used leverage as a determinant of share prices in examining its effect on share price in the Nigeria Stock Exchange market from 2006 to 2010. After regressing the data, their finding revealed that leverage has a significant positive effect on share price. The result of their study was corroborated by the study of Zeitun and Tian (2007) who investigated the effect of capital structure on corporate performance of corporations in Jordan on 167 companies from 1989 to 2003 revealed that leverage has a significant positive effect on stock market performance.

The study of Ekene (2016) investigated the impact of monetary policy rate on stock returns in Nigeria from 2003 to 2014. The study used a six-variable standard VAR model with six lags \{consumer price index (CPI), interbank rate (IBR), open buy-back (OBB), Treasury bill rate (TBR), exchange rate (XGR), and all share index (ASI) to measure monetary policy rate. Their result revealed that monetary policy rate was insignificantly positive on stock returns. The study of Osuagwu (2009) investigated the impact of monetary policy variables on the performance of the stock market in Nigeria from 1984 to 2007. The study used the ordinary least squares, cointegration, and error-correction specification models to analyse data. The result revealed that minimum rediscount rate and treasury bills which are direct variables of monetary policy were insignificantly positive on performance of stock market.

Theories relevant to this study include efficient market hypothesis, arbitrage pricing, extreme event. All these theories describe the response of stock return to market risk factors. However, the arbitrage pricing theory forms 
the bedrock of the study. This is because market factors that are both firm specific and macroeconomic influence stock return. The Arbitrage Pricing Theory (APT) states that there is a set of underlying sources that influence all stock returns. In other words, APT suggests that market returns which include stock return can be explained in terms of a number of systematic risk factors as well as macroeconomic factors. The APT is a development over the capital asset pricing model that calculates a single beta. APT assumes that a security return is a linear function, not only of one, but also a set of common factors. This is corroborated by Ross (1976) who suggested that other economy-wide factors could also systematically affect the returns for a large number of securities and these factors include information about inflation, interest rates, gross domestic product (GDP), or the unemployment rate. Changes in these factors may affect future firm's earning and result in a change in the measurement of market risk and discounting of future cash flow. Iqbal and Haider (2005) also opined that these set of common factors are interrelated and as the asset sensitivity to each factor increases the risk premium also increases and vice versa.

The emergence of APT into financial literatures has created a platform for empirical studies. Studies like Acikalin, Aktas and Unal (2008), Ali (2013), Ibrahim and Musah (2014), and Kirui, Wawire and Onono (2014) found that APT is useful in relating changes in returns on investments to unanticipated changes in a range of key value drivers that are firm specific and macroeconomic in nature. In addition, their studies support the position that one market factor of beta cannot fully explain the variance in stock return but dependent on other market factors.

\section{Methodology}

The population of the study consists of fifty-six (56) financial service firms listed in the Nigeria Stock Exchange (appendix A1). The study adopted a purposive sampling technique and filtering criteria to arrive at a sample size that best represents the population. The selection of sample financial service firms in the Nigerian Stock Exchange (NSE) from 2007 to 2018 was based on the availability of data for financial service firms as well as the maintaining of their identity despite change in their status (holding companies) and has been listed before the change was effected. In view of these filtering criteria, a sample size of twenty-nine (29) listed financial service firms which comprises thirteen (13) deposit money banks, fourteen (14) insurance firms, one (1) mortgage bank, and one (1) other financial institution were used (appendix A2).

Secondary data were sourced from audited annual reports of financial service firms to compute market risk indicative ratios, fact books of NSE and websites of other financial institutions (FSL Securities and Global Business News) to make available stock prices for a period of twelve (12) years spanning from 2007 to 2018 . The data sourced to represent stock return was collected on a monthly basis in order to arrive at annual average. In addition, the stock price for the month of January 2007 was used as the base share price for the lag year 2006 in order to arrive at the annual average return for the preceding year 2007. This is because some of the firms were listed in 2006; and for uniformity and availability of data. The data for market capitalization of firms were also collected on a monthly basis to arrive at the annual average. Nevertheless, the MPR data were collected on a monthly basis to arrive at the annual average MPR in percentage. The variables used for the study were clearly defined with their measurement as captured in Table 1.

The study used the multiple regression model which captured the effect of the independent variables on the dependent variable. The model is described as follows:

$S T R_{i t}=\alpha_{0}+\beta_{1} B M R_{i t}+\beta_{2} N I M_{i t}+\beta_{3} F_{S Z} Z_{i t}+\beta_{4} L V R_{i t}+\beta_{5} M P R_{i t}+\mathcal{E}_{i t} \ldots \ldots \ldots . . .$. Model. STR is represented as stock return, $\alpha_{0}$ as constant term, $\beta$ as coefficient of independent variable of book-to-market ratio (BMR), net interest margin (NIM), control variables of firm size (FSZ), leverage (LVR), monetary policy rate (MPR), and $\varepsilon$ as error term. In testing the normality of data, the Shapiro-Wilki test was used to confirm the data fitness and whether sample data have the skewness and kurtosis of matching a normal distribution. In addition, the objective is to reject the null hypothesis that the data is no different from normal. The study measured the explanatory or predictive power of the regression model and how well the linear regression equation fits the data by employing R-squared. The R-squared or coefficient of determination is the proportion of variance (\%) in the dependent variable that can be explained by the independent variable. As a rule of thumb for interpreting the strength of the relationship among the variables, an R-squared value should be equal to or greater than 0.10 in order for the variance explained of a particular endogenous construct to be deemed adequate (Falk and Miller, 1992). 
Table 1

Variable, Definition, Measurement, and Sources

\begin{tabular}{|c|c|c|c|c|}
\hline $\begin{array}{ll}\text { Type } & \text { of } \\
\text { Variable } & \\
\end{array}$ & Variable & Variable Measurement & Description & Source \\
\hline Dependent & $\begin{array}{l}\text { Stock } \\
\text { Return }\end{array}$ & $\begin{array}{l}\mathrm{Rt}=\mathrm{Ln}\left(\frac{\mathrm{Pt}}{\mathrm{P}_{\mathrm{t}-1}}\right) \\
\text { where } \mathrm{Rt} \text { is annual average stock return } \\
\text { at time } \mathrm{t} \text {, where } \mathrm{Pt} \& \mathrm{P}_{\mathrm{t}-1} \text { are annual } \\
\text { average price of stock at two successive } \\
\text { years } t \text { and } \mathrm{t}-1 \text { respectively. }\end{array}$ & $\begin{array}{l}\text { Natural Logarithm of } \\
\text { the annual average stock } \\
\text { price at two successive } \\
\text { years of sample firms } \\
\text { listed on the NSE. }\end{array}$ & $\begin{array}{l}\text { Isa } \\
\text { Yakob } \\
(2013)\end{array}$ \\
\hline Independent & $\begin{array}{l}\text { Book-to- } \\
\text { Market } \\
\text { Ratio }\end{array}$ & $\begin{array}{l}\text { BMR=Shareholders' Funds /Annual } \\
\text { Average Market Capitalisation } \\
\text { Where BMR is book-to - market ratio }\end{array}$ & $\begin{array}{l}\text { Book-to-Market ratio } \\
\text { measured annually of } \\
\text { sample firms listed on } \\
\text { the NSE }\end{array}$ & $\begin{array}{l}\text { Chen et al. } \\
(2005)\end{array}$ \\
\hline Independent & $\begin{array}{l}\text { Net } \\
\text { Interest } \\
\text { Margin }\end{array}$ & $\begin{array}{l}\text { NIM= Net Interest/Total Asset } \\
\text { Where NIM is net interest margin, net } \\
\text { interest is difference between interest } \\
\text { income and interest expense }\end{array}$ & $\begin{array}{l}\text { Ratio of net interest } \\
\text { (interest income less } \\
\text { interest expense) to total } \\
\text { asset of sample firms } \\
\text { listed on the NSE } \\
\text { measured annually }\end{array}$ & $\begin{array}{l}\text { Mwaurah } \\
\text { et al. } \\
(2017)\end{array}$ \\
\hline Control & $\begin{array}{l}\text { Firm } \\
\text { Size }\end{array}$ & $\begin{array}{l}\text { VTS }=\operatorname{Ln}\left(\frac{\text { VTS } 1+\text { VTS } 2}{2}\right) \\
\text { Where VTS is Value of Traded Shares } \\
\text { (Naira), Where VTS is Value of Traded } \\
\text { Shares (Naira), where VTS } 1 \text { \& VTS } 2 \\
\text { are closing share price by traded volume } \\
\text { in January and December for a period } \\
\text { respectively }\end{array}$ & $\begin{array}{l}\text { Natural Logarithm } \\
\text { Average Annual Value } \\
\text { of Traded Share of } \\
\text { sample firms listed on } \\
\text { the NSE measured } \\
\text { annualy }\end{array}$ & $\begin{array}{l}\text { Chan } \\
\text { Fong } \\
(2000)\end{array}$ \\
\hline Control & Leverage & Total Liabilities to Total Assets & $\begin{array}{l}\text { Ratio of } \\
\text { Liabilities to Total } \\
\text { Assets of sample firms } \\
\text { listed on the NSE } \\
\text { measured annually }\end{array}$ & $\begin{array}{l}\text { Demirovic } \\
(2013)\end{array}$ \\
\hline Control & $\begin{array}{l}\text { Monetar } \\
\text { y Policy } \\
\text { Rate }\end{array}$ & $\begin{array}{l}\mathrm{MPR}=\mathrm{Ln} \text { of Annual Average MPR in } \\
\text { percentage; Where MPR is monetary } \\
\text { policy rate }\end{array}$ & $\begin{array}{l}\text { Log of Annual Average } \\
\text { MPR measured } \\
\text { annually. }\end{array}$ & $\begin{array}{l}\text { Okpara } \\
(2010)\end{array}$ \\
\hline
\end{tabular}

\section{Source: Authors' Compilation, 2020}

The study used the multiple regression model which captured the effect of the independent variables on the dependent variable. The model is described as follows:

$S T R_{i t}=\alpha_{0}+\beta_{1} B M R_{i t}+\beta_{2} N I M_{i t}+\beta_{3} F S Z_{i t}+\beta_{4} L V R_{i t}+\beta_{5} M P R_{i t}+\varepsilon_{i t} \ldots . . . \ldots . .$. Model. STR is represented as stock return, $\alpha_{0}$ as constant term, $\beta$ as coefficient of independent variable of book-to-market ratio (BMR), net interest margin (NIM), control variables of firm size (FSZ), leverage (LVR), monetary policy rate (MPR), and $\mathcal{E}$ as error term. In testing the normality of data, the Shapiro-Wilki test was used to confirm the data fitness and whether sample data have the skewness and kurtosis of matching a normal distribution. In addition, the objective is to reject the null hypothesis that the data is no different from normal. The study measured the explanatory or predictive power of the regression model and how well the linear regression equation fits the data by employing $\mathrm{R}$-squared. The R-squared or coefficient of determination is the proportion of variance (\%) in the dependent variable that can be explained by the independent variable. As a rule of thumb for interpreting the strength of the relationship among the variables, an R-squared value should be equal to or greater than 0.10 in order for the variance explained of a particular endogenous construct to be deemed adequate (Falk and Miller, 1992).

Test for multicollinearity was performed to check the high level of intercorrelation among the explanatory variables such that their effects cannot be separated. Multicollinearity was measured by variance inflation factors (VIF) and tolerance. The study considered the rule of thumb of VIF value not exceeding 4.0 or tolerance value less than 0.2 to conclude absence of multicollinearity (Hair et al.,2010). Nevertheless, the Breusch-Pagan/CookWeisberg test for heteroskedasticity was performed to determine whether the variance of the errors from a regression is dependent on the values of the explanatory variables. The decision rule established the rejection of the null hypothesis (homoscedasticity) with p-value less than level of significance at 5\% (Hair et al.,2010). To establish the panel effect of data, an F-test and Wald $\mathrm{Chi}^{2}$ test were conducted to determine the suitability of the 
fixed effects model and random-effects model respectively. The choice of using either the fixed-effect or random effect model for the study was determined by the Hausman test.

\section{Results and Discussions}

The results and discussions for the study were based on the tables as explained below.

Table 2

Descriptive Statistics

\begin{tabular}{llllll}
\hline Variables & Mean & SD & Min & Max & Obs \\
\hline STR & 1.0401 & 0.6827 & 0.1200 & 7.6400 & 348 \\
BMR & 2.1697 & 2.7557 & -2.7286 & 19.9694 & 348 \\
NIM & 0.2743 & 0.7197 & -0.6692 & 8.2549 & 348 \\
FSZ & 24.3215 & 8.8419 & 8.0400 & 39.1200 & 348 \\
LVR & 0.5193 & 0.1604 & 0.2194 & 0.6820 & 348 \\
MPR & 0.1092 & 0.0248 & 0.0608 & 0.1400 & 348 \\
\hline
\end{tabular}

Source: STATA OUTPUT (Appendix B)

The result in Table 2 revealed that the average value of stock return of sample firms was 1.0401 within a period of 12 years. In other words, the change in stock price contributed to a stock return of $104.01 \%$ with a deviation of $68.27 \%$. The minimum rate of stock return was $12 \%$ and a maximum rate of $764 \%$. According to Kassi, Rathnayake, Louembe \& Ding (2019) a ratio of less than one denotes an overvalued firm while a rate of more than one indicates an undervalued firm. Within the period of review, book-to-market ratio revealed that financial service firms were undervalued as compared to the average return on stock. The average net interest margin of the firms was $27.43 \%$ with a deviation of $71.97 \%$. The average firm size of the firms in terms of market capitalization stood at N24.32 Billion Naira with a deviation of 8.84 Billion Naira. The result further revealed that financial service firms leveraged on debts by $51.93 \%$ over equity of $48.07 \%$.

The study also tested for normality of data and the result is revealed in Table 3.

Table 3

Normality Test

\begin{tabular}{llllll}
\hline Variables & W & V & Z & P-Values & Obs \\
\hline STR & 0.6377 & 88.077 & 10.587 & 0.0000 & 348 \\
BMR & 0.6032 & 96.468 & 10.802 & 0.0000 & 348 \\
NIM & 0.3309 & 162.649 & 12.037 & 0.0000 & 348 \\
FSZ & 0.9766 & 5.684 & 4.108 & 0.0002 & 348 \\
LVR & 0.8183 & 44.162 & 8.955 & 0.0000 & 348 \\
MPR & 0.9480 & 12.633 & 5.996 & 0.0000 & 348 \\
\hline
\end{tabular}

Source: STATA OUTPUT (Appendix B)

The Shapiro-Wilk (W) test was conducted to check the normality of the data. Table 3 revealed that data from the variables of the models are non-normally distributed because the P-values of all the variables are significant at the level of $1 \%$ ( $p$-values of 0.0000 ).

The study tested for suitability of the model and the result is stated in Table 4.

Table 4

Robust OLS Regression Model Summary

\begin{tabular}{lll}
\hline Variables & Statistics & P-Values \\
\hline R Square & 0.2765 & \\
F-Statistics & 27.67 & 0.0000 \\
Hausman Chi2 & 2.55 & 0.7693 \\
Hettest: Chi2 & 91.28 & 0.0000 \\
Mean VIF & 1.12 & \\
Random Effect (LM) Test: Chi2 & 0.00 & 1.0000 \\
\hline
\end{tabular}

\section{Source: STATA OUTPUT (Appendix B)}

The classical regression assumptions of Ordinary Least Square (OLS) on panel data require the model to be fit and unbiased for a valid inferences and conclusions. As such, this study subjected the model to fixed and random effects regression, OLS, and other robustness tests to achieve a reliable result as revealed in Table 4. The test for heteroskedasticity was employed using the Breuch Pagan/Cook-Weisberg test which revealed $\mathrm{Chi}^{2}$ of 91.28 with a p-value of 0.0000 indicating the presence of heteroskedasticity in the panel data. The assumption of constant variance of the error term (homocedasticity) is not supported and as a result OLS estimators may not be best linear unbiased estimators (BLUE). However, this is corrected using robust OLS (heteroskedasticity corrected standard errors). The Hausman specification test of $\mathrm{Chi}^{2} 2.55$ with a p-value of 0.7693 suggested the suitability of random effect model for the study. A further test on the result of a random effect test by employing the Breusch and Pagan 
Lagrangian Multiplier Test for random effects revealed that there is no statistical significant variance among the units in the panel (Chibar2 of 0.00 with a p-value of 1.0000). Therefore, the OLS regression model was deemed suitable for the study.

A mean variable inflation factor of 1.12 as revealed in Table 4 suggested the absence of perfect multicolinearity among the explanatory variables. This agreed with the rule of thumb of VIF not exceeding 4 . The R-squared of 0.2765 in Table 4 revealed that the model explained $27.65 \%$ of the total variations in the dependent variable. The result from Table 4 further revealed that the model is fit from the F-Statistic of 27.67 which is statistically significant at $1 \%$ level of significance (as indicated by the P-value of 0.0000 ).

Hypotheses Testing

The hypotheses formulated for the study are tested and analysed using the results in Table 5.

Table 5

Robust OLS Estimators

\begin{tabular}{lll}
\hline Variables & Coefficients & P-Values \\
\hline BMR & -0.0319 & 0.131 \\
NIM & 0.1493 & 0.037 \\
FSZ & 0.0701 & 0.000 \\
LVR & 2.8847 & 0.000 \\
MPR & 1.8366 & 0.468 \\
CONSTANT & -1.5480 & 0.000 \\
\hline
\end{tabular}

Source: STATA OUTPUT (Appendix B)

Ho1: Book-to-Market Ratio has no significant effect on Stock Return of Listed Financial Service Firms in Nigeria

The result of hypothesis test revealed an insignificant negative effect of book-to-market ratio (BMR) on stock return of financial service firms with a coefficient of -0.0319 and p-value of 0.131 at $5 \%$ significance level. The result obtained from the regression estimators supported the study of Agbam et al. (2018), though the study of Gautam (2017) and Kassi et al. (2019) revealed a significant negative effect. However, the result did not support the study of Morelli (2017) and Akwe et al. (2018) which found a positive effect of book-to-market ratio on stock return. Therefore, the result supported the null hypothesis that there is no significant effect between book-to-market ratio and stock return. The result revealed that the higher the book-market ratio the lower the stock return and vice versa (Wang \& Xu, 2004; Arshad et al., 2015).

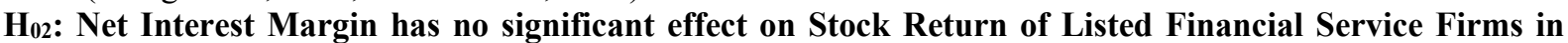
Nigeria

The result of the hypothesis test revealed a significant positive effect of net interest margin on stock return of financial service firms with a coefficient of 0.1493 and p-value of 0.037 at $5 \%$ significance level. The result obtained from the regression estimators supported the study of Iskandar (2020), though the study of Akwe et al. (2018) revealed an insignificant positive effect. According to Iskandar (2020), a firm's financial performance through improved net interest margin increases stock return for investors. However, the result did not support the study of Gautam (2017), Muriithi et al. (2016), and Nurazi \& Usman (2016) who revealed that net interest margin had a negative effect on stock returns.

The Controlling Effect of Firm Size, Leverage, and Monetary Policy Rate on Stock Return of Listed Financial Service Firms in Nigeria

The result of hypothesis test revealed a significance positive effect of firm size on stock return of financial service firms with a coefficient of 0.0701 and p-value of 0.000 at $5 \%$ significant level. The result obtained from the regression estimators supports the study of Handayani et al. (2019) and Agbam et al. (2018). The effect of leverage on stock return was significantly positive with a coefficient of 2.8847 and p-value of 0.000 at $5 \%$ significance level. The result obtained from the regression estimators supports the study of Uwuigbe et al. (2012) and Zeitun $\&$ Tian (2007). The result supported the assertion that the higher the leverage the higher the return on stock for leveraged firms operating in a favourable economic condition. The effect of monetary policy rate was insignificantly positive on stock return with a coefficient of 1.8366 and p-value of 0.468 at $5 \%$ significance level. The result obtained from the regression estimators supports the study of Ekene (2016) and Osuagwu (2009). The insignificant effect could be as a result of the form of market efficiency and the equity culture in the stock market. In addition, the result explained that an increase or decrease in MPR has less effect on the prices of shares.

\section{Conclusion and Recommendations}

The study examined the effect of market risk on stock return of listed financial service firms in Nigeria with controlling effect of firm size, leverage, and monetary policy rate. The study concluded that book-to-market ratio (BMR) revealed an insignificant negative effect on stock return. This is an indication that a higher BMR will result in a lower stock return. Also, the study concluded that net interest margin (NIM) significantly and positively affects stock return. The result is an indication that stock return reacts to growth in firms' NIM. Apparently, the arbitrage 
pricing theory supports the assumptions that firm specific factors other than beta, affect stock return.

Considering the conclusion established from the findings of the study, some recommendations were made.

Market risk is systematic in nature that investors cannot eliminate through a diversified portfolio. However, it can be reduced through hedging strategy. Therefore, decision-makers and portfolio managers of financial service firms should employ appropriate risk strategies through derivatives, forwards, futures, swaps, options that can mitigate market risk. Investing firms should continuously review their net interest margin which is a significant factor of performance as the higher the value the higher the return.

\section{References}

Abbass, K., Song, H., Shah, S. M., \& Aziz, B. (2019). Determinants of stock return for non- financial sector: Evidence from energy sector of Pakistan. A Journal of Business and Financial Affairs, 8 (1), ISSN: 21670234, DOI: $10.4172 / 2167-0234.1000370$.

Acikalin, S., Aktas, R., \& Unal, S. (2008). Relationships between stock markets and macroeconomic variables: An empirical analysis of the Istanbul stock exchange. Investment Management and Financial Innovations, 5 (1), 7-16.

Afrivest Securities Limited. (2018). The Nigerian economy and financial market. A 2017 Review \& 2018 Outlook.

Afrivest Securities Limited. (2018). The Nigerian insurance sector report: Unlocking potentials for growth. $A 2017$ Review \& 2018 Outlook.

Agbam, A. S., Anyamaobi, C., \& Udo, E. O. (2018). Firm size, book-to-market equity and the stock returns: Analysis of Nigerian stock market. A World Journal of Finance and Investment Research, 3 (1), ISSN 25507125, www.iiardpub.org.

Akwe, J. A., Garba, S. B., \& Dang, Y. D. (2018). Effects of macroeconomic factors on stock returns in Nigeria. An International Journal of Finance and Accounting, 3 (1), pp 66- 82, ISSN 2513-4311X (online).

Alagidede, P., \& Panagiotidis, T. (2009). Modelling stock returns in Africa's emerging equity markets. AnInternationalReviewofFinancialAnalysis. DOI:10.1016/j.irfa.2009.02.001

Ali, M.B. (2013). The impact of selected micro and macroeconomic variables on the stock prices of emerging stock market: A case of Dhaka stock exchange (DSE). Doctor of Philosophy Dissertation, University of Dhaka.

Arshad, Z., Arshaad, A. R., Yousaf, S., \& Jamil, S. (2015). Determinants of share prices of listed commercial banks in Pakistan. Journal of Economics and Finance, 3(2), 56-64.

Badawi, A. (2017). Effect of credit risk, liquidity risk, and market risk banking to profitability bank: Study on devised banks in Indonesia stock exchange. European Journal of Business and Management 9, 1-8.

Banz, R.W. (1981). The relationship between return and market value of common stocks. Journal of Financial Economics, 9, 3-18.

Belke, A., \& Polleit, T. (2004). How do stock market returns react to monetary policy? An ARDL Cointegration Analysis for Germany, 22.

Bomfim, A. N. (2001) Pre-announcement effects, news effects, and volatility: Monetary policy and the stock market, Journal of Banking \& Finance (s. 133-151).

Chan, K., \& Fong, W. M. (2000). Trade size, order imbalance, and the volatility-volume relation. Journal of Financial Economics, 57, 247-273.

Chen, J., Chollete, L., \& Ray, R. (2010). Financial distress and idiosyncratic volatility: An empirical investigation. Journal of Financial Markets,13 (2), pp 249-267.

Choudhry, M., Turner, S., Landuyt, G., \& Butt, K. (2008).The global financial crisis 2007- 2009: The impact on the banking industry.World Commerce Review 3,(2).Page 1-49.

Daferighe, E. E., \& Aje, S. O. (2009). An impact analysis of real gross domestic product, inflation and interest rates on stock prices of quoted companies in Nigeria. International Research Journal of Finance and Economics, 25, pp 53-63.

Daniel, K., Hirshleifer, D., \& Teoh, S. H. (2002). Investor psychology in capital markets: Evidence and policy implications. A Journal of Monetary Economics, 49, 139-209.

Demirovic, A. (2013). The interaction between equity and credit risks. A Ph D thesis submitted in partial fulfillment of the requirements of Bristol Business School, University of the West of England Bristol.

Ekene, O. C. (2016). Impact of monetary policy on stock returns in Nigeria. Middle-East J Journal of Scientific Research 24 (5): ISSN 1778-1787, DOI: 10.5829/idosi.mejsr.2016.24.05.23455

English, W. B. (2002). Interest rate risk and bank net interest margins. A BIS Quarterly Review, 67-82.

Fahmi, S., Geetha, C., \& Mohidin, R. (2017). The effect of systematic risk factors on the performance of the Malaysia stock market. A Proceedings of International Conference on Economics Proceedings, pp 57-68, ISBN 978-967-0521-99-2

Falk, R. F., \& Miller, N. B. (1992). A primer for soft modeling, Ohio: University of Akon Press

Fama, E. F., \& French, K. R. (1992). The cross section of expected stock returns. A Journal of Finance 47, 427- 
466.

FSL Securities Limited (n.d.). Nigeria stock exchange pricelist: Research agenda. Retrieved March,15,2020, from https:// www.fsl.ng/pricelist.php

Gautam, R. (2017). Impact of firm specific variables on stock price volatility and stock returns of Nepalese commercial banks. International Journal of Research in Business Studies and Management,4(6),33-44, ISSN 2394-5923(Print) \& ISSN 2394-5931 (Online).

Global Business News (n.d.). Global stock prices and financials of international finance companies: Research Agenda on Nigeria listed financial service firms. Retrieved March, 20,2020, from https://ng.investing.com/equities/historical data

Gupta R., Modise, M. P. (2011). Macroeconomic variables and South African stock return predictability. $A$ Working Paper.

Hair, J. F., Black, W. C., Babin, B. J., \& Anderson, R. E. (2010). Multivariate data analysis. (7th ed.), Pearson, New York.

Handayani, M., Farlian, T., \& Ardian, A. (2019). Firm size, market risk, and stock return: Evidence from Indonesian blue chip companies. Jurnal Dinamika Akuntansi dan Bisnis, 6(2), pp 171-182 , https:// dx.doi.org/10.24815/jdab.v612.13082.

Ibrahim, M., \& Musah, A. (2014). An econometric analysis of the impact of macroeconomic fundamentals on stock market returns in Ghana. Research in Applied Economics, 6 (2), 47-72.

Idris, I., \& Bala, H. (2015). Firms' specific characteristics and stock market returns: Evidence from listed food and beverages firms in Nigeria. Research Journal of Finance and Accounting, 6 (16), 188 - 201.

Ioannidis, C. \& Kontonikas, A. (2008). The impact of monetary policy on stock prices. Journal of Policy Modelling, $30,33-55$.

Iqbal, J., \& Haider, A. (2005). Arbitrage pricing theory: Evidence from an emerging stock market. Lahore Journal of Economics 10(1),123-139

Isa, Z. B., \& Yakob, R. B. (2013). Stock return and market risk: A comparison between conventional insurance and takaful. An African Journal of Business Management, 7 (8), pp. 591-597. Available online at http://www.academicjournals.org/AJBM DOI: 10.5897/AJBM11.416 ISSN 1993-8233.

Iskandar, Y. (2020). The influence of capital adequacy ratio, loan-to-deposit ratio, and net interest margin on stock return at commercial banks in Indonesia. Jurnal Aplikasi Manajemen,18,(3),Pages,533538,Malang:UniversitasBrawijaya. http://dx.doi.org/10.21776/ub.jam.2020.018.03.13

Karolyi, G. A. (2001). Why stock return volatility really matters. Journals Institutional Investor Series, 6 (14), pp $1-16$.

Kassi, D. F., Rathnayake, D. N., Louembe, P. A., \& Ding, N. (2019). Market risk and financial performance of non-financial companies listed on the Moroccan stock exchange. Article.

Kirui, E., Wawire, N. H. W., \& Onono, P. O. (2014). Macroeconomic variables, volatility and stock market returns: A case of Nairobi securities exchange, Kenya. International Journal of Economics and Finance, 6 (8); ISSN 1916-971X E-ISSN 1916-9728, doi:10.5539/ijef.v6n8p214.

Leledakis, G., Davidson, I., \& Smith, J. (2004). Does firm size predict stock returns? Evidence from the London Stock Exchange. DOI:10.2139/ssrn.492283.

Llorente G, Michaely, R., Saar, G., \& Wang, J. (2002). Dynamic volume-return relation of individual stocks. The Review of Financial Studies, 15 (4), pp 1005-1047.

Morelli, D. (2007). Beta, size, book-to-market equity and returns. A study based on UK data. Journal of Multinational Financial Management, 11(3): 9-16.

Muriithi, J. G, Muturi, W. M., \& Waweru, K. M. (2016). The effect of market risk on financial performance of commercial banks in Kenya. Journal of Finance and Accounting 4(4), 225-233.

Mwaurah, I. G. (2019). Influence of financial risk on stock returns of commercial banks listed in Nairobi securities exchange. A PhD Dissertation on Finance, Jomo Kenyatta University of Agriculture and Technology.

Mwaurah, I. G., Muturi, W., \& Waititu, A. (2017). The influence of credit risk on stock returns. International Journal of Scientific and Research Publications, 7 (5), 575, ISSN:2250-3153.

Nurazi, R., \& Usman, B. (2016). Bank stock returns in responding the contribution of fundamental and macroeconomic effects. A Jurnal Keuangan dan Perbankan, 9 (1), pp 129-144. DOI: http://dx.doi.org/10.15294/jejak.v9i1.7191.

Okpara, G. C. (2010). Monetary policy and stock market returns: Evidence from Nigeria. Journal of Economics, 1(1),13-21.

Onuoha, T. E., \& Nwaiwu, J. N. (2016). Impact of global financial crisis in Nigeria stock market. An international multidisciplinary. Journal of African Research Review, 10 (1), pp 166-177. http://dx.doi.org/10.4314/afrrev.v10i1.13.

Osamwonyi, I. O., \& Asein, E. I. (2012). Market risk and returns: Evidence from the Nigerian capital market. Asian Journal of Business Management,4 (4), 367-372, ISSN:2041-8752. 
Osuagwu, E.S. (2009). The effect monetary policy on stock market performance in Nigeria. Nigeria Journal of Securities and Finance, 14 (2).

Reichert, A., \& Shyu, Y. (2003). Derivative activities and the risk of international banks: A market index and VaR approach. An International Review of Financial Analysis, 12, 489- 511.

Ross, S. A. (1976). The arbitrage theory of capital asset pricing. Journal of Economic Theory, 13, 341-360.

Serrasqueiro, Z. S., Nunes, P. M. (2008). Performance and size: Empirical evidence from Portuguese SMEs. $A$ Journal of Business Economics, 31 (2), pp 195 - 217.

Shafana, M. A., Rimziya, A. L., \& Jariya, A. M. (2013). Relationship between stock returns and firm size, and book-to-market equity: Empirical evidence from selected companies listed on milanka price index in Colombo stock exchange. Journal of Emerging Trends in Economics and Management Sciences, 4 (2), 217 225.

Sukcharoensin, P. (2013). Time-varying market, interest rate and exchange rate risks of Thai commercial banks. Asian Academy of Management Journal of Accounting and Finance,9 (1), 25-45.

Syauta, K. \& Widjaja. T. 2009. Analysis of return on asset, loan deposit ratio, net interest margin, and nonperforming loan on abnormal return of commercial banks in Indonesia. Journal of Applied Finance and Accounting, 1 (2) pp $351-367$.

Uwuigbe, U., Olusegun, O., \& Godswill, A. (2012). An Assessment of the determinants of share price in Nigeria: A study of selected listed firms. ACTA Universities Danubius, 8(6), 26-41.

Wang, F. \& Xu, Y. (2004). What determines Chinese stock returns? A Journal of Financial Analysis, 60 (6),pp 6577, https://dx.doi.org/10.2139/ssrn.581801.

Yang, C. H., \& Chen, K. H. (2009). Are small firms less efficient? A Journal of Business Economics, 32 (4), $375-$ 395.

Zaigham, G. H. K., Wang, X., \& Ali, H. S. (2019). Causal relation between stock market performance and firm investment in China: Mediating role of information asymmetry. SAGE Journal (1),13, DOI: $10.1177 / 2158244019885146$.

Zeitun, R., \& Tian, G.G. (2007). Capital structure and corporate performance: Evidence from

Jordan. A Journal of Accounting, Business and Finance, 1 (4), 40- 53.

Appendix A1: Population Frame of the Study

\begin{tabular}{|c|c|c|c|c|c|c|c|}
\hline $\mathbf{S N}$ & Deposit Money Banks & DL & DOI & $\mathbf{S N}$ & $\begin{array}{l}\text { Listed Insurance } \\
\text { Companies (Ticker) }\end{array}$ & DL & DOI \\
\hline 1. & $\begin{array}{l}\text { Access } \\
\text { (Access) }\end{array}$ & $18 / 11 / 98$ & $8 / 2 / 89$ & 1. & $\begin{array}{lr}\text { African } & \text { Alliance } \\
\text { Insurance } & \text { Plc } \\
\text { (Afrinsure) } & \end{array}$ & $17 / 9 / 09$ & $6 / 5 / 60$ \\
\hline 2. & Diamond Bank Plc & $27 / 5 / 05$ & $20 / 12 / 90$ & 2. & $\begin{array}{l}\text { Aiico Insurance } \mathrm{Plc} \\
\text { (Aiico) }\end{array}$ & $31 / 12 / 89$ & $14 / 7 / 70$ \\
\hline 3. & $\begin{array}{l}\text { EcoBank Transnational } \\
\text { Incorporated }\end{array}$ & $11 / 9 / 06$ & $3 / 10 / 85$ & 3. & $\begin{array}{l}\text { Axamansard Insurance } \\
\text { Plc (Mansard) }\end{array}$ & $19 / 11 / 09$ & $23 / 6 / 89$ \\
\hline 4. & Fidelity Bank Plc & $17 / 5 / 05$ & $19 / 11 / 87$ & 4. & $\begin{array}{l}\text { Consolidated Hallmark } \\
\text { Insurance Plc (Chiplc) }\end{array}$ & $22 / 2 / 08$ & $2 / 8 / 91$ \\
\hline 5. & $\begin{array}{l}\text { First Bank Nigeria } \\
\text { Holding Plc }\end{array}$ & $26 / 11 / 12$ & $13 / 8 / 12$ & 5. & $\begin{array}{l}\text { Continental } \\
\text { Reinsurrance } \quad P l c \\
\text { (Continsure) }\end{array}$ & $30 / 5 / 07$ & $24 / 4 / 85$ \\
\hline 6. & $\begin{array}{l}\text { First City Monument } \\
\text { Bank Plc }\end{array}$ & $21 / 12 / 04$ & $20 / 4 / 82$ & 6. & $\begin{array}{l}\text { Cornerstone Insurance } \\
\text { Plc (Cornerst) }\end{array}$ & $13 / 8 / 97$ & $26 / 7 / 91$ \\
\hline 7. & $\begin{array}{l}\text { Guaranty Trust Bank } \\
\text { Plc }\end{array}$ & $9 / 9 / 96$ & $20 / 7 / 90$ & 7. & $\begin{array}{l}\text { Goldlink Insurance Plc } \\
\text { (Goldinsure) }\end{array}$ & $12 / 2 / 08$ & $8 / 9 / 93$ \\
\hline 8. & Jaiz Bank Plc & $9 / 1 / 17$ & $1 / 4 / 03$ & 8. & $\begin{array}{ll}\text { Great } & \text { Nigerian } \\
\text { Insurance Plc } & (\mathrm{Gni}) *\end{array}$ & 2005 & $24 / 2 / 1960$ \\
\hline 9. & Stanbic IBTC Bank Plc & $23 / 11 / 12$ & $14 / 3 / 12$ & 9. & $\begin{array}{l}\text { Guinea Insurance Plc } \\
\text { (Guineans) }\end{array}$ & $1 / 1 / 90$ & $3 / 12 / 58$ \\
\hline 10. & Sterling Bank Plc & $2 / 1 / 06$ & $25 / 11 / 04$ & 10. & $\begin{array}{lr}\text { International } & \text { Energy } \\
\text { Insurance } & \mathrm{Plc} \\
\text { (Intenegins) } & \end{array}$ & $13 / 7 / 07$ & $28 / 3 / 69$ \\
\hline 11. & $\begin{array}{l}\text { Union Bank of Nigeria } \\
\text { Plc }\end{array}$ & 1917 & 1971 & 11. & $\begin{array}{l}\text { Lasaco Assurance Plc } \\
\text { (Lasaco) }\end{array}$ & $20 / 12 / 79$ & $20 / 12 / 79$ \\
\hline 12. & $\begin{array}{l}\text { United Bank of Africa } \\
\text { Plc }\end{array}$ & $31 / 3 / 70$ & $23 / 2 / 61$ & 12. & $\begin{array}{l}\text { Law Union And Rock } \\
\text { Insurance } \\
\text { (Lawunion) }\end{array}$ & $9 / 7 / 90$ & $17 / 6 / 69$ \\
\hline
\end{tabular}




\begin{tabular}{|c|c|c|c|c|c|c|c|}
\hline 13. & Unity Bank Plc & $22 / 12 / 05$ & $27 / 4 / 05$ & 13. & $\begin{array}{l}\text { Linkage Assurance Plc } \\
\text { (Linkassure) }\end{array}$ & $18 / 11 / 03$ & $26 / 3 / 91$ \\
\hline 14. & Wema Bank Plc & $13 / 2 / 90$ & $2 / 5 / 45$ & 14. & $\begin{array}{l}\text { Mutual } \quad \text { Benefits } \\
\text { Assurance (MBenefit) }\end{array}$ & $28 / 5 / 02$ & $18 / 4 / 95$ \\
\hline 15. & Zenith Bank Plc & $21 / 10 / 04$ & $30 / 5 / 90$ & 15 . & $\begin{array}{l}\text { NEM Insurance Plc } \\
(\mathrm{Nem})\end{array}$ & $5 / 9 / 90$ & $2 / 4 / 70$ \\
\hline SN & Mortgage Banks & & & 16. & $\begin{array}{l}\text { Niger Insurance Plc } \\
\text { (Nigerins) }\end{array}$ & $1 / 9 / 93$ & $29 / 8 / 62$ \\
\hline 1. & $\begin{array}{l}\text { Abbey Mortgage Bank } \\
\text { Plc }\end{array}$ & $21 / 10 / 08$ & $26 / 8 / 91$ & 17. & $\begin{array}{l}\text { Prestige Assurance Plc } \\
\text { (Prestige) }\end{array}$ & $3 / 12 / 90$ & $6 / 1 / 70$ \\
\hline 2. & $\begin{array}{l}\text { African Prudential Plc } \\
\text { (Afriprud) }\end{array}$ & $11 / 1 / 13$ & $23 / 3 / 06$ & 18. & $\begin{array}{l}\text { Regency Assurance Plc } \\
\text { (Regalins) }\end{array}$ & $27 / 5 / 08$ & $16 / 6 / 93$ \\
\hline 3. & $\begin{array}{l}\text { Aso Savings \& Loans } \\
\text { Plc } \\
\text { (Aso Savings) }\end{array}$ & $25 / 4 / 08$ & $9 / 11 / 95$ & 19. & $\begin{array}{lr}\text { Sovereign } & \text { Trust } \\
\text { Insurance } & \mathrm{Plc} \\
\text { (Sovrenins) } & \end{array}$ & $29 / 11 / 06$ & $26 / 2 / 80$ \\
\hline 4. & $\begin{array}{l}\text { Infinity Trust Mortgage } \\
\text { Bank Plc (Infinity) }\end{array}$ & $11 / 12 / 13$ & $1 / 1 / 92$ & 20. & $\begin{array}{l}\text { Staco Insurance Plc } \\
(\text { Staco) }\end{array}$ & $25 / 6 / 7$ & $10 / 7 / 91$ \\
\hline 5. & $\begin{array}{l}\text { Resort Savings \& Loans } \\
\text { Plc (Regalins) }\end{array}$ & $23 / 11 / 09$ & $17 / 6 / 92$ & 21. & $\begin{array}{l}\text { Standard } \\
\text { Insurance } \\
\text { (Stdinsure) }\end{array}$ & $19 / 12 / 03$ & $28 / 7 / 81$ \\
\hline 6. & $\begin{array}{l}\text { Omoluabi } \quad \text { Mortgage } \\
\text { Bank Plc (Omomobnk) }\end{array}$ & $14 / 11 / 14$ & 9/3/99 & 22. & $\begin{array}{lr}\text { Sunu } & \text { Assurances } \\
\text { Nigeria Plc (Sunuassur) }\end{array}$ & $18 / 7 / 07$ & $3 / 12 / 84$ \\
\hline 7. & $\begin{array}{l}\text { Union Homes } \\
\text { and Savings } \\
\text { (Unhomes) }\end{array}$ & $24 / 4 / 06$ & $6 / 11 / 92$ & 23. & $\begin{array}{l}\text { Unic Diversified } \\
\text { Holdings Plc (Unic) }\end{array}$ & $11 / 9 / 15$ & $2 / 4 / 65$ \\
\hline SN & Micro Finance Banks & & & 24. & $\begin{array}{l}\text { Universal Insurance Plc } \\
\text { (Univinsure) }\end{array}$ & $11 / 2 / 08$ & $1 / 3 / 61$ \\
\hline 1. & $\begin{array}{l}\text { Fortis Micro Finance } \\
\text { Bank Plc (Fortis MFB) }\end{array}$ & $20 / 6 / 12$ & $18 / 6 / 7$ & 25. & $\begin{array}{lr}\text { Veritas } & \text { Kapital } \\
\text { Assurance } & \mathrm{Plc} \\
\text { (Veritaskap) } & \end{array}$ & $17 / 12 / 09$ & $8 / 8 / 3$ \\
\hline 2. & $\begin{array}{l}\text { NPF Micro Finance } \\
\text { Bank Plc (NPFM crfbk) }\end{array}$ & $1 / 12 / 10$ & $19 / 5 / 93$ & 26. & $\begin{array}{l}\text { Wapic Insurance Plc } \\
\text { (Wapic) }\end{array}$ & 1990 & $14 / 3 / 58$ \\
\hline
\end{tabular}

\section{SN Other Financial} Institutions

1. Custodian Investment $12 / 6 / 07 \quad 22 / 8 / 91$

Plc

(Custodian)

2. Deap Capital Mgt \& 17/12/07 5/6/02

Trust Plc (DeaCap)

3. Nigeria Energy Sector 18/6/99 26/10/98

Fund (NESF)

4. Royal Exchange Plc 3/12/90 18/7/89

(Royalex)

5. United Capital Plc 1/11/13 14/3/02 (UCAP)

6. Value Alliance Value 27/7/11 2010 Fund Plc (Valuefund)

Source: Generated by author from the Central Bank of Nigeria Official Website and Nigerian Stock Exchange website.

Notes: DL represents Date of Listing; DOI represents Date of Incorporation.

*: Delisted in 2018

**: Name change but retained identity 


\begin{tabular}{|c|c|c|}
\hline $\mathbf{S} / \mathbf{N}$ & Listed Financial Service Firms & Industry \\
\hline 1. & Áccess Bank Plc & Banking \\
\hline 2. & Diamond Bank Plc & Banking \\
\hline 3. & EcoBank Transnational Incorporated & Banking \\
\hline 4. & Fidelity Bank Plc & Banking \\
\hline 5. & First Bank Nigeria Holding & Banking \\
\hline 6. & First City Monument Bank Plc & Banking \\
\hline 7. & Guaranty Trust Bank Plc & Banking \\
\hline 8. & Sterling Bank Plc & Banking \\
\hline 9. & Union Bank of Nigeria Plc & Banking \\
\hline 10. & United Bank For Africa Plc & Banking \\
\hline 11. & Unity Bank Plc & Banking \\
\hline 12. & Wema Bank Plc & Banking \\
\hline 13. & Zenith Bank Plc & Banking \\
\hline 14 & Aiico Insurance Plc (Aiico) & Insurance \\
\hline 15. & Cornerstone Insurance Plc (Cornerst) & Insurance \\
\hline 16 & Guinea Insurance Plc (Guineans) & Insurance \\
\hline 17. & Lasaco Assurance Plc (Lasaco) & Insurance \\
\hline 18. & Law Union And Rock Insurance Plc (Lawunion) & Insurance \\
\hline 19. & Linkage Assurance Plc (Linkassure) & Insurance \\
\hline 20. & Mutual Benefits Assurance (MBenefit) & Insurance \\
\hline 21. & NEM Insurance Plc (Nem) & Insurance \\
\hline 22. & Niger Insurance Plc (Nigerins) & Insurance \\
\hline 23. & Prestige Assurance Plc (Prestige) & Insurance \\
\hline 24. & Sovereign Trust Insurance Plc (Sovrenins) & Insurance \\
\hline 25. & Standard Alliance Insurance Plc (Stdinsure) & Insurance \\
\hline 26. & Unic Diversified Holdings Plc (Unic) & Insurance \\
\hline 27. & Wapic Insurance Plc (Wapic) & Insurance \\
\hline 28. & Union Homes Savings and Loans Plc (Unhomes) & Mortgage Bank \\
\hline 29. & Royal Exchange Plc (Royalex) & Other Financial Institutions \\
\hline
\end{tabular}

Source: Author's Compilation (2020).

\section{APPENDIX A3: Summary of Raw Data}

Firm Year STR "N"

Access

Access

Access

Access

Access

Access

Access

Access

Access

Access

Access

Access

Diamond

Diamond

Diamond

Diamond

Diamond

Diamond

Diamond

Diamond

Diamond

Diamond

$\begin{array}{lll}2007 & 1.84 & 0.2676 \\ 2008 & 0.95 & 1.2182 \\ 2009 & 0.42 & 1.8812 \\ 2010 & 1.28 & 1.2016 \\ 2011 & 0.81 & 1.4130 \\ 2012 & 1.04 & 1.8869 \\ 2013 & 1.44 & 1.1725 \\ 2014 & 0.83 & 1.5137 \\ 2015 & 0.64 & 2.8608 \\ 2016 & 0.92 & 3.0055 \\ 2017 & 1.70 & 1.6435 \\ 2018 & 1.16 & 1.5791 \\ 2007 & 1.43 & 0.1024 \\ 2008 & 0.95 & 0.5985 \\ 2009 & 0.48 & 1.3213 \\ 2010 & 1.05 & 1.0157 \\ 2011 & 0.65 & 0.4226 \\ 2012 & 0.60 & 2.0119 \\ 2013 & 2.17 & 1.3466 \\ 2014 & 0.98 & 6.7307 \\ 2015 & 0.58 & 2.6818 \\ 2016 & 0.40 & 7.9694\end{array}$

\section{Net Int
Ratio}

Book-To-Mk

.8812

.2016

.8869

1.1725

5137

3.0055

1.6435

.5791

0.5985

1.3213

1.0157

0.4226

2.0119

6.7307

2.6818

7.9694
FSZ "N'M"

0.0546

0.0251

0.0466

0.0495

0.0535

0.0561

0.0391

0.0447

0.0373

0.0375

0.0376

0.0274

0.0509

0.0377

0.0380

0.0897

0.0980

0.0843

0.0731

0.0778

0.0821

0.0642

\subsection{5}

15.9995

963.5730

$1,730.6600$

2,492.9900

$1,340.5200$

$23,999.5600$

$1,847.1400$

$2,468.9200$

$1,216.8150$

$2,559.6650$

$7,659.2800$

290.5485

82.7950

51.8600

$1,242.7000$

$1,542.1800$

845.0250

$2,302.9350$

$1,647.9000$

685.0800

490.0500
LVR Ratio

1.3733

0.8338

0.7393

0.7821

0.8030

0.8432

0.8561

0.8617

0.8506

0.8645

0.8671

0.8889

0.8274

0.8061

0.8209

0.7869

0.8720

0.7869

0.8979

0.8825

0.8662

0.8729 


\begin{tabular}{|c|c|c|c|c|c|c|}
\hline Firm & Year & STR "N" & $\begin{array}{l}\text { Book-To-Mkt } \\
\text { Ratio }\end{array}$ & $\begin{array}{l}\text { Net Int. Margin } \\
\text { Ratio }\end{array}$ & FSZ "N'M" & LVR Ratio \\
\hline Diamond & 2017 & 0.77 & 6.7307 & 0.0795 & 471.9500 & 0.8740 \\
\hline Diamond & 2018 & 1.55 & 0.4964 & 0.0971 & $3,923.1400$ & 0.9793 \\
\hline ECOBank & 2007 & 1.11 & 34822.3510 & 0.0426 & 21.0790 & 0.8820 \\
\hline ECOBank & 2008 & 1.56 & 0.3147 & 0.0425 & 5.5960 & 0.9266 \\
\hline ECOBank & 2009 & 1.93 & 0.0012 & 0.0002 & 2.5180 & 0.9236 \\
\hline ECOBank & 2010 & 0.64 & 1.3581 & 0.0643 & $1,113.4050$ & 0.8524 \\
\hline ECOBank & 2011 & 0.85 & 1.6138 & 0.0055 & 991.2250 & 0.9305 \\
\hline ECOBank & 2012 & 0.78 & 11.1797 & 0.0558 & $1,289.5450$ & 0.8760 \\
\hline ECOBank & 2013 & 1.32 & 156628.0000 & 0.0608 & $5,144.7500$ & 0.8855 \\
\hline ECOBank & 2014 & 1.14 & 1.4187 & 0.0998 & $3,967.5600$ & 0.8544 \\
\hline ECOBank & 2015 & 1.17 & 1.4198 & 0.1236 & $4,044.7400$ & 0.8284 \\
\hline ECOBank & 2016 & 0.74 & 2.5061 & 0.2263 & 248.6050 & 0.8122 \\
\hline ECOBank & 2017 & 1.02 & 2.4093 & 0.0518 & $1,231.7350$ & 0.9032 \\
\hline ECOBank & 2018 & 1.36 & 2.1370 & 0.1711 & 642.9000 & 0.8681 \\
\hline Fidelity & 2007 & 2.16 & 0.2375 & 0.0406 & 148.2710 & 0.8630 \\
\hline Fidelity & 2008 & 0.94 & 0.8484 & 0.0414 & 23.1310 & 0.7452 \\
\hline Fidelity & 2009 & 0.33 & 1.5500 & 0.0302 & 11.8225 & 0.7020 \\
\hline Fidelity & 2010 & 0.89 & 1.7846 & 0.0530 & 556.6737 & 0.7050 \\
\hline Fidelity & 2011 & 0.88 & 2.2193 & 0.0414 & 912.5150 & 0.8021 \\
\hline Fidelity & 2012 & 0.70 & 2.9405 & 0.0403 & 430.2700 & 0.8234 \\
\hline Fidelity & 2013 & 1.83 & 1.9286 & 0.0285 & $1,154.3800$ & 0.8488 \\
\hline Fidelity & 2014 & 0.77 & 3.5248 & 0.0411 & 374.5400 & 0.8542 \\
\hline Fidelity & 2015 & 0.71 & 3.8502 & 0.0494 & 351.9900 & 0.8510 \\
\hline Fidelity & 2016 & 1.44 & 6.2427 & 0.0477 & 142.6000 & 0.8572 \\
\hline Fidelity & 2017 & 0.83 & 3.6867 & 0.0494 & $1,021.3450$ & 0.8540 \\
\hline Fidelity & 2018 & 1.73 & 2.4805 & 0.0405 & $2,078.7850$ & 0.8870 \\
\hline First Bank & 2007 & 1.09 & 77351.0000 & 0.1825 & 603.469 & 0.9082 \\
\hline First Bank & 2008 & 0.89 & 96257.0000 & 0.1388 & 281.0855 & 0.7698 \\
\hline First Bank & 2009 & 0.45 & 317488.0000 & 0.2049 & $2,469.3485$ & 0.8209 \\
\hline First Bank & 2010 & 0.74 & 340735.0000 & 0.2270 & $5,919.5900$ & 0.8295 \\
\hline First Bank & 2011 & 0.90 & 377244.0000 & 0.2267 & $14,265.8000$ & 0.8707 \\
\hline First Bank & 2012 & 1.04 & 1.4510 & 0.2248 & $3,730.2250$ & 0.8728 \\
\hline First Bank & 2013 & 1.41 & 0.6238 & 0.1912 & $6,393.8100$ & 0.8978 \\
\hline First Bank & 2014 & 0.76 & 1.3075 & 0.1815 & $7,758.7850$ & 8.7935 \\
\hline First Bank & 2015 & 0.58 & 1.8039 & 0.1850 & $3,690.2600$ & 0.8611 \\
\hline First Bank & 2016 & 0.50 & 4.0605 & 0.2000 & $1,204.2100$ & 0.8770 \\
\hline First Bank & 2017 & 1.54 & 2.4729 & 0.2404 & $3,958.4200$ & 0.8713 \\
\hline First Bank & 2018 & 1.89 & 1.4423 & 0.1652 & $10,424.6050$ & 0.9047 \\
\hline FCMB & 2007 & 2.00 & 0.4930 & 0.0361 & 214.5075 & 0.8817 \\
\hline FCMB & 2008 & 1.00 & 1.4117 & 0.0442 & 92.4985 & 0.7140 \\
\hline FCMB & 2009 & 0.43 & 1.9248 & 0.0313 & 749.3925 & 0.7205 \\
\hline FCMB & 2010 & 1.06 & 1.3991 & 0.0354 & $1,080.1850$ & 0.7518 \\
\hline FCMB & 2011 & 0.77 & 1.6694 & 0.0520 & 658.7150 & 0.8049 \\
\hline FCMB & 2012 & 0.69 & 2.5777 & 0.0412 & 456.4800 & 0.8547 \\
\hline FCMB & 2013 & 1.23 & 1.8404 & 0.0573 & $2,492.2200$ & 0.8575 \\
\hline FCMB & 2014 & 0.90 & 2.0012 & 0.5521 & $1,048.0750$ & 0.0060 \\
\hline FCMB & 2015 & 0.66 & 2.5978 & 0.4942 & 827.7900 & 0.0079 \\
\hline FCMB & 2016 & 0.45 & 1.1526 & 0.5293 & 819.4300 & 0.0096 \\
\hline FCMB & 2017 & 1.06 & 4.7962 & 0.5358 & 491.1650 & 0.0151 \\
\hline FCMB & 2018 & 1.78 & 2.8476 & 0.5465 & $2,979.3950$ & 0.0127 \\
\hline GTB & 2007 & 1.19 & 0.1445 & 0.0687 & 729.3375 & 0.9008 \\
\hline GTB & 2008 & 0.85 & 0.5410 & 0.1806 & 328.5800 & 0.8045 \\
\hline GTB & 2009 & 0.48 & 0.9010 & 0.3574 & $2,305.5045$ & 0.8152 \\
\hline GTB & 2010 & 1.04 & 0.5501 & 0.2908 & $5,251.5850$ & 0.8074 \\
\hline GTB & 2011 & 1.14 & 0.5429 & 0.1856 & $5,732.2800$ & 0.8455 \\
\hline GTB & 2012 & 1.15 & 0.5294 & 0.2277 & $4,568.6800$ & 0.8232 \\
\hline GTB & 2013 & 1.51 & 0.4342 & 0.1806 & $7,820.1250$ & 0.8269 \\
\hline
\end{tabular}




\begin{tabular}{|c|c|c|c|c|c|c|}
\hline Firm & Year & STR "N" & $\begin{array}{l}\text { Book-To-Mkt } \\
\text { Ratio }\end{array}$ & $\begin{array}{l}\text { Net Int. Margin } \\
\text { Ratio }\end{array}$ & FSZ "N'M" & LVR Ratio \\
\hline GTB & 2014 & 1.04 & 0.5250 & 0.1561 & $12,800.6250$ & 0.8308 \\
\hline GTB & 2015 & 0.90 & 0.5673 & 0.1814 & $10,416.9050$ & 0.8219 \\
\hline GTB & 2016 & 0.86 & 0.7979 & 0.2059 & $3,213.5400$ & 0.8187 \\
\hline GTB & 2017 & 1.62 & 0.5255 & 0.2036 & $9,960.6050$ & 0.7952 \\
\hline GTB & 2018 & 1.19 & 0.4155 & 0.1715 & $16,432.1400$ & 0.8113 \\
\hline Sterling & 2007 & 1.55 & 31272.0210 & 0.0419 & 16.0885 & 0.8164 \\
\hline Sterling & 2008 & 0.89 & 1.9892 & 0.0475 & 48.6335 & 0.8721 \\
\hline Sterling & 2009 & 0.27 & 1.2959 & 0.0606 & 5.6240 & 0.7923 \\
\hline Sterling & 2010 & 1.25 & 1.0475 & 0.0555 & 188.2000 & 0.8944 \\
\hline Sterling & 2011 & 0.85 & 1.6248 & 0.0331 & 320.8050 & 0.9185 \\
\hline Sterling & 2012 & 0.73 & 2.2332 & 0.0412 & 116.2950 & 0.9196 \\
\hline Sterling & 2013 & 2.24 & 1.4994 & 0.0506 & $1,002.3800$ & 0.9103 \\
\hline Sterling & 2014 & 0.83 & 1.7021 & 0.0522 & 667.3550 & 0.8973 \\
\hline Sterling & 2015 & 0.89 & 1.6392 & 0.0495 & 743.0550 & 0.8805 \\
\hline Sterling & 2016 & 0.61 & 2.6336 & 0.0674 & 72.4750 & 0.8969 \\
\hline Sterling & 2017 & 0.70 & 2.7816 & 0.0469 & 138.9250 & 0.9049 \\
\hline Sterling & 2018 & 1.81 & 1.7089 & 0.0511 & 653.2050 & 0.9096 \\
\hline Union & 2007 & 1.32 & 66770.0000 & 0.0944 & 514.0370 & 0.8441 \\
\hline Union & 2008 & 0.98 & 125263.0000 & 0.0607 & 58.8935 & 0.8773 \\
\hline Union & 2009 & 0.41 & 253910.0000 & 0.0299 & 203.0375 & 1.2756 \\
\hline Union & 2010 & 1.58 & -135894.0000 & 0.0515 & 414.1100 & 1.1706 \\
\hline Union & 2011 & 0.55 & 13.3740 & 0.0266 & $3,022.4450$ & 0.7837 \\
\hline Union & 2012 & 0.44 & 2.3800 & 0.0708 & 131.8250 & 0.8063 \\
\hline Union & 2013 & 1.82 & 1.2299 & 0.0625 & 208.8200 & 0.7871 \\
\hline Union & 2014 & 0.89 & 1.4832 & 0.0708 & 94.9250 & 1.2906 \\
\hline Union & 2015 & 0.88 & 1.7462 & 0.0701 & 139.2950 & 1.3043 \\
\hline Union & 2016 & 0.60 & 0.1294 & 0.0074 & $1,737.0750$ & 1.2872 \\
\hline Union & 2017 & 1.19 & 2.7027 & 0.0614 & 169.1450 & 1.3142 \\
\hline Union & 2018 & 1.03 & 0.9922 & 0.0453 & 399.3700 & 1.1780 \\
\hline UBA & 2007 & 1.20 & 0.3934 & 0.0381 & 563.2610 & 0.8505 \\
\hline UBA & 2008 & 0.78 & 0.4464 & 0.0469 & 308.2430 & 0.8762 \\
\hline UBA & 2009 & 0.31 & 0.9969 & 0.0775 & $3,692.4455$ & 0.8660 \\
\hline UBA & 2010 & 0.68 & 0.7434 & 0.0437 & $2,345.4550$ & 0.8700 \\
\hline UBA & 2011 & 0.61 & 1.0298 & 0.0337 & $2,953.4250$ & 0.8906 \\
\hline UBA & 2012 & 0.77 & 2.0488 & 0.0387 & $1,111.9150$ & 0.8860 \\
\hline UBA & 2013 & 2.11 & 0.9980 & 34.3535 & $4,384.7600$ & 0.8830 \\
\hline UBA & 2014 & 0.88 & 1.7940 & 0.0351 & $2,518.3450$ & 0.8795 \\
\hline UBA & 2015 & 0.62 & 2.1794 & 0.0464 & $1,106.0950$ & 0.8474 \\
\hline UBA & 2016 & 0.97 & 2.7382 & 0.0428 & $1,568.9300$ & 0.8461 \\
\hline UBA & 2017 & 1.99 & 1.1965 & 0.0451 & $2,939.4600$ & 0.8627 \\
\hline UBA & 2018 & 1.25 & 1.0634 & 0.0380 & $5,238.8950$ & 0.8985 \\
\hline Unity & 2007 & 1.01 & 0.2851 & 0.0297 & 137.7090 & 0.8424 \\
\hline Unity & 2008 & 0.88 & 0.2325 & 0.0459 & 140.7490 & 0.9484 \\
\hline Unity & 2009 & 0.27 & 0.3721 & 0.0649 & 6.6850 & 0.9720 \\
\hline Unity & 2010 & 6.96 & 1.6592 & 0.0541 & 125.2950 & 0.8553 \\
\hline Unity & 2011 & 0.84 & 0.6686 & 0.0605 & 228.1250 & 0.8825 \\
\hline Unity & 2012 & 0.58 & 2.8539 & 0.0638 & 28.2500 & 0.8700 \\
\hline Unity & 2013 & 1.24 & 1.2762 & 0.0747 & 904.8750 & 0.9301 \\
\hline Unity & 2014 & 0.79 & 1.3048 & 0.1100 & 96.7750 & 0.8155 \\
\hline Unity & 2015 & 0.54 & 3.9798 & 0.0972 & $1,016.6950$ & 0.8137 \\
\hline Unity & 2016 & 0.28 & 11.3754 & 0.1004 & 31.2400 & 0.8313 \\
\hline Unity & 2017 & 0.80 & -34.5319 & 0.3270 & 521.2800 & 2.5475 \\
\hline Unity & 2018 & 1.74 & -14.7851 & 0.0592 & 267.7000 & 2.0327 \\
\hline Wema & 2007 & 1.89 & 0.2558 & 0.0719 & 66.9615 & 0.8475 \\
\hline Wema & 2008 & 1.65 & -0.1331 & -0.0161 & 225.7460 & 1.2530 \\
\hline Wema & 2009 & 0.26 & 0.5793 & 0.0335 & 14.0125 & 1.4021 \\
\hline Wema & 2010 & 0.29 & 1.8810 & 0.0629 & 122.5000 & 0.9473 \\
\hline
\end{tabular}




\begin{tabular}{|c|c|c|c|c|c|c|}
\hline Firm & Year & STR "N" & $\begin{array}{l}\text { Book-To-Mkt } \\
\text { Ratio }\end{array}$ & $\begin{array}{l}\text { Net Int. Margin } \\
\text { Ratio }\end{array}$ & FSZ "N'M" & LVR Ratio \\
\hline Wema & 2011 & 0.90 & 0.4590 & 0.0453 & 136.5650 & 0.9717 \\
\hline Wema & 2012 & 0.50 & 0.1899 & 0.0479 & 36.2300 & 0.9948 \\
\hline Wema & 2013 & 2.37 & 1.3984 & 0.0379 & 103.7750 & 0.8749 \\
\hline Wema & 2014 & 0.83 & 1.1729 & 0.0485 & 139.4750 & 0.8856 \\
\hline Wema & 2015 & 0.95 & 1.2088 & 0.0447 & 176.6850 & 0.8839 \\
\hline Wema & 2016 & 0.79 & 1.9958 & 0.0443 & 326.4950 & 0.8849 \\
\hline Wema & 2017 & 0.69 & 2.4079 & 0.0514 & 14.5300 & 0.8709 \\
\hline Wema & 2018 & 1.53 & 1.4216 & 0.0565 & 779.5200 & 0.8933 \\
\hline Zenith & 2007 & 1.45 & 0.2796 & 0.0490 & 448.3200 & 0.8274 \\
\hline Zenith & 2008 & 0.86 & 0.7504 & 0.0523 & 99.9135 & 0.7985 \\
\hline Zenith & 2009 & 0.38 & 1.2068 & 0.0656 & 826.2155 & 0.7913 \\
\hline Zenith & 2010 & 0.92 & 0.8189 & 0.0475 & $13,017.2000$ & 0.8151 \\
\hline Zenith & 2011 & 1.00 & 0.8624 & 0.0597 & $18,004.5000$ & 0.8768 \\
\hline Zenith & 2012 & 1.09 & 0.8736 & 0.0607 & $7,422.8300$ & 0.8203 \\
\hline Zenith & 2013 & 1.40 & 0.6285 & 0.0646 & $10,153.1550$ & 0.8358 \\
\hline Zenith & 2014 & 1.07 & 0.7785 & 0.0542 & $8,576.9000$ & 0.8503 \\
\hline Zenith & 2015 & 0.79 & 0.9569 & 0.0540 & $6,576.4300$ & 0.8542 \\
\hline Zenith & 2016 & 0.79 & 1.4596 & 0.0494 & $5,533.4900$ & 0.8574 \\
\hline Zenith & 2017 & 1.46 & 0.9556 & 0.0454 & $10,778.1250$ & 0.8556 \\
\hline Zenith & 2018 & 1.25 & 0.7811 & 0.0492 & $18,103.5350$ & 0.8638 \\
\hline AIICO & 2007 & 1.28 & 0.9201 & 0.3108 & 9.5760 & 0.5964 \\
\hline AIICO & 2008 & 1.13 & 1.3911 & 0.1500 & 4.6345 & 0.4768 \\
\hline AIICO & 2009 & 0.26 & 2.5969 & 0.1565 & 102.9870 & 0.4978 \\
\hline AIICO & 2010 & 1.01 & 3.9790 & 0.2018 & 72.2900 & 0.5588 \\
\hline AIICO & 2011 & 0.67 & 1.9447 & 0.6154 & 71.7350 & 0.6517 \\
\hline AIICO & 2012 & 0.71 & 2.5166 & 0.2868 & 30.4300 & 0.6676 \\
\hline AIICO & 2013 & 1.70 & 1.4145 & 0.1178 & 88.7950 & 0.7449 \\
\hline AIICO & 2014 & 0.92 & 1.5586 & 0.0912 & 48.3450 & 0.7989 \\
\hline AIICO & 2015 & 1.09 & 1.5025 & 0.0000 & 66.9650 & 0.8810 \\
\hline AIICO & 2016 & 0.81 & 1.5430 & 0.2291 & 14.0550 & 0.8927 \\
\hline AIICO & 2017 & 0.77 & 2.8990 & 0.0059 & 185.1000 & 0.8814 \\
\hline AIICO & 2018 & 1.25 & 2.7580 & 0.1342 & 44.6900 & 0.8539 \\
\hline Cornerstone & 2007 & 2.12 & 0.5344 & 0.2394 & 87.1650 & 0.2367 \\
\hline Cornerstone & 2008 & 1.12 & 0.1716 & 0.3309 & 17.9235 & 0.3234 \\
\hline Cornerstone & 2009 & 0.28 & 1.0094 & 0.2385 & 26.7980 & 0.3630 \\
\hline Cornerstone & 2010 & 0.54 & 1.2914 & 0.2961 & 15.3100 & 0.3972 \\
\hline Cornerstone & 2011 & 0.88 & 1.2666 & 0.2600 & 1.6750 & 0.4771 \\
\hline Cornerstone & 2012 & 1.01 & 1.3650 & -0.4430 & 6.7000 & 0.4902 \\
\hline Cornerstone & 2013 & 1.00 & 1.4902 & 0.2343 & 17.2400 & 0.5011 \\
\hline Cornerstone & 2014 & 0.99 & 1.3650 & 0.0000 & 9.8700 & 0.4524 \\
\hline Cornerstone & 2015 & 1.00 & 2.2999 & 0.3151 & 158.7000 & 0.4340 \\
\hline Cornerstone & 2016 & 1.00 & 1.1283 & 0.3376 & 110.7250 & 0.5476 \\
\hline Cornerstone & 2017 & 1.00 & 0.8413 & 0.2190 & 36.3750 & 0.7022 \\
\hline Cornerstone & 2018 & 0.61 & 1.8125 & 0.3701 & 11.4000 & 0.6890 \\
\hline Guinea Ins. & 2007 & 2.69 & 2.3459 & 0.0530 & 6.2790 & 0.1334 \\
\hline Guinea Ins. & 2008 & 1.87 & 1.7495 & 0.2184 & 2.4345 & 0.1840 \\
\hline Guinea Ins. & 2009 & 0.24 & 8.7232 & 0.2597 & 0.8127 & 0.2189 \\
\hline Guinea Ins. & 2010 & 0.83 & 8.7255 & 0.2275 & 65.2250 & 1.0000 \\
\hline Guinea Ins. & 2011 & 1.00 & 1.7305 & 0.2674 & 23.2700 & 0.3403 \\
\hline Guinea Ins. & 2012 & 1.00 & 0.9489 & 0.2166 & 10.7738 & 0.3527 \\
\hline Guinea Ins. & 2013 & 1.00 & 1.0340 & 0.1813 & 0.8250 & 0.2921 \\
\hline Guinea Ins. & 2014 & 1.00 & 0.9435 & 0.1862 & 89.3550 & 0.3655 \\
\hline Guinea Ins. & 2015 & 1.00 & 0.7920 & 0.1460 & 42.0900 & 0.2955 \\
\hline Guinea Ins. & 2016 & 1.00 & 0.9585 & 0.2158 & 78.4750 & 0.2710 \\
\hline Guinea Ins. & 2017 & 1.00 & 1.1095 & 0.2173 & 99.0970 & 0.2264 \\
\hline Guinea Ins. & 2018 & 0.71 & 1.1764 & 0.2366 & 62.4850 & 0.2548 \\
\hline Lasaco & 2007 & 2.49 & 1.6244 & 0.1752 & 123.9325 & 0.2945 \\
\hline
\end{tabular}




\begin{tabular}{|c|c|c|c|c|c|c|}
\hline Firm & Year & STR "N" & $\begin{array}{l}\text { Book-To-Mkt } \\
\text { Ratio }\end{array}$ & $\begin{array}{l}\text { Net Int. Margin } \\
\text { Ratio }\end{array}$ & FSZ "N'M" & LVR Ratio \\
\hline Lasaco & 2008 & 1.17 & 0.2470 & 0.2258 & 106.8905 & 0.3121 \\
\hline Lasaco & 2009 & 0.28 & 1.0322 & 2138346.0000 & 18.4530 & 1.0000 \\
\hline Lasaco & 2010 & 0.58 & 1.2634 & 0.1042 & 20.9350 & 0.3634 \\
\hline Lasaco & 2011 & 1.00 & 1.4027 & 0.3053 & 7.7900 & 0.4093 \\
\hline Lasaco & 2012 & 1.00 & 1.4821 & 0.2276 & 221.5700 & 0.4458 \\
\hline Lasaco & 2013 & 1.00 & 1.5837 & 0.2110 & 38.3550 & 0.4819 \\
\hline Lasaco & 2014 & 1.00 & 1.7528 & 0.0860 & 76.3350 & 0.5493 \\
\hline Lasaco & 2015 & 1.00 & 1.7966 & 0.0391 & 68.7800 & 0.5922 \\
\hline Lasaco & 2016 & 1.00 & 2.1443 & 0.2808 & 1.6850 & 0.5679 \\
\hline Lasaco & 2017 & 1.00 & 2.2275 & 0.2537 & 1.4300 & 0.5608 \\
\hline Lasaco & 2018 & 0.68 & 3.2178 & 0.3649 & 5.1700 & 0.5025 \\
\hline Law Union & 2007 & 1.19 & 0.4756 & 0.4110 & 40.4535 & 0.2267 \\
\hline Law Union & 2008 & 1.27 & 0.5959 & 0.5007 & 22.5880 & 0.3730 \\
\hline Law Union & 2009 & 0.25 & 1.0155 & 0.4725 & 0.4012 & 0.3392 \\
\hline Law Union & 2010 & 0.46 & 2.5207 & 0.4612 & 34.2800 & 0.3702 \\
\hline Law Union & 2011 & 0.96 & 2.5963 & 0.4852 & 14.1650 & 0.3693 \\
\hline Law Union & 2012 & 0.95 & 1.9520 & 0.3680 & 28.7950 & 0.4590 \\
\hline Law Union & 2013 & 1.00 & 2.3800 & 0.3936 & 2.4950 & 0.3961 \\
\hline Law Union & 2014 & 1.00 & 1.6224 & 0.3519 & 127.9050 & 0.4266 \\
\hline Law Union & 2015 & 1.09 & 2.4245 & 0.1492 & 56.9300 & 0.4611 \\
\hline Law Union & 2016 & 1.17 & 2.9324 & -0.6692 & 1.4300 & 0.4127 \\
\hline Law Union & 2017 & 1.29 & 1.9671 & 0.0087 & 1.8000 & 0.3555 \\
\hline Law Union & 2018 & 0.92 & 1.9263 & 0.0573 & 4.2000 & 0.4317 \\
\hline Linkage & 2007 & 2.71 & 0.4507 & -508570.0000 & 3.6885 & 1.0000 \\
\hline Linkage & 2008 & 0.91 & 0.2902 & 2013697.0000 & 24.8840 & 1.0000 \\
\hline Linkage & 2009 & 0.21 & 1.5900 & 0.2490 & 1.9020 & 0.0000 \\
\hline Linkage & 2010 & 0.94 & 3.8002 & 0.1711 & 182.9800 & 0.2282 \\
\hline Linkage & 2011 & 1.00 & 3.5648 & 0.1141 & 110.3100 & 0.2214 \\
\hline Linkage & 2012 & 1.00 & 5.7709 & -0.2054 & 69.8550 & 0.1239 \\
\hline Linkage & 2013 & 1.00 & 3.8420 & -0.2440 & 208.6950 & 0.1336 \\
\hline Linkage & 2014 & 1.00 & 3.8969 & -0.1335 & 0.4403 & 0.1329 \\
\hline Linkage & 2015 & 1.00 & 4.0774 & 0.1262 & 3.5455 & 0.1633 \\
\hline Linkage & 2016 & 1.00 & 3.5632 & -0.1068 & 35.3650 & 0.1869 \\
\hline Linkage & 2017 & 1.40 & 4.3002 & 0.0773 & 9.0250 & 0.1440 \\
\hline Linkage & 2018 & 1.09 & 2.6827 & 0.0331 & 9.6600 & 0.2257 \\
\hline Mutual Benefits & 2007 & 3.89 & 0.4703 & 0.2098 & 19.9465 & 0.3815 \\
\hline Mutual Benefits & 2008 & 1.06 & 0.2328 & 0.2303 & 24.4650 & 0.4827 \\
\hline Mutual Benefits & 2009 & 0.27 & 1.0990 & 0.2074 & 0.2585 & 0.5094 \\
\hline Mutual Benefits & 2010 & 0.61 & 1.5654 & 0.2433 & 23.1500 & 0.4844 \\
\hline Mutual Benefits & 2011 & 0.95 & 2.0123 & 0.3217 & 20.6400 & 0.5213 \\
\hline Mutual Benefits & 2012 & 1.00 & 0.7846 & 0.2599 & 171.4350 & 0.6413 \\
\hline Mutual Benefits & 2013 & 1.00 & 0.8263 & 0.1104 & 211.0950 & 0.9261 \\
\hline Mutual Benefits & 2014 & 1.01 & 1.3872 & 0.2290 & 231.2650 & 0.8527 \\
\hline Mutual Benefits & 2015 & 0.99 & 1.5503 & 0.1975 & 115.2100 & 0.8349 \\
\hline Mutual Benefits & 2016 & 1.00 & 1.2027 & 0.1099 & 24.4450 & 0.8637 \\
\hline Mutual Benefits & 2017 & 1.40 & 1.3667 & 0.0930 & 134.5250 & 0.8563 \\
\hline Mutual Benefits & 2018 & 0.47 & 1.9960 & 0.0994 & 1.2850 & 0.8541 \\
\hline NEM Insurance & 2007 & 2.97 & 0.4232 & 0.4091 & 101.7343 & 0.2340 \\
\hline NEM Insurance & 2008 & 1.01 & 0.2979 & 0.6575 & 32.5125 & 0.1921 \\
\hline NEM Insurance & 2009 & 0.24 & 1.7628 & 5.0348 & 15.0740 & 6.4442 \\
\hline NEM Insurance & 2010 & 0.72 & 2.1173 & 3.6582 & 22.7000 & 5.3679 \\
\hline NEM Insurance & 2011 & 0.99 & 2.3515 & 0.7404 & 26.7000 & 0.1903 \\
\hline NEM Insurance & 2012 & 0.95 & 1.5950 & 0.8650 & 73.6450 & 0.4306 \\
\hline NEM Insurance & 2013 & 1.44 & 1.1778 & 0.5546 & 199.4450 & 0.5134 \\
\hline NEM Insurance & 2014 & 1.04 & 3.4361 & 0.6209 & 169.5150 & 0.4625 \\
\hline NEM Insurance & 2015 & 0.89 & 2.4869 & 0.5026 & 10.1700 & 0.4865 \\
\hline NEM Insurance & 2016 & 1.20 & 2.0387 & 0.1627 & 51.3300 & 0.4886 \\
\hline
\end{tabular}




\begin{tabular}{|c|c|c|c|c|c|c|}
\hline Firm & Year & STR "N" & $\begin{array}{l}\text { Book-To-Mkt } \\
\text { Ratio }\end{array}$ & $\begin{array}{l}\text { Net Int. Margin } \\
\text { Ratio }\end{array}$ & FSZ "N'M" & LVR Ratio \\
\hline NEM Insurance & 2017 & 1.33 & 1.4992 & 0.6389 & 24.8500 & 0.4459 \\
\hline NEM Insurance & 2018 & 2.52 & 1.0230 & 0.5257 & $2,214.7850$ & 0.4460 \\
\hline Niger Insurance & 2007 & 1.24 & 0.6718 & 0.0844 & 50.4435 & 0.5320 \\
\hline Niger Insurance & 2008 & 1.36 & 0.4313 & 0.2662 & 3.5180 & 0.6971 \\
\hline Niger Insurance & 2009 & 0.28 & 1.4311 & 0.3336 & 6.6020 & 0.7837 \\
\hline Niger Insurance & 2010 & 0.40 & 1.4463 & 0.2389 & 9.0050 & 0.8877 \\
\hline Niger Insurance & 2011 & 0.87 & 1.2694 & 0.3024 & 10.7450 & 0.7346 \\
\hline Niger Insurance & 2012 & 0.85 & 2.1036 & 0.3456 & 27.6950 & 0.6739 \\
\hline Niger Insurance & 2013 & 1.00 & 2.0367 & -0.1279 & 32.7600 & 0.6741 \\
\hline Niger Insurance & 2014 & 1.00 & 2.0533 & 0.2857 & 2.3150 & 0.6423 \\
\hline Niger Insurance & 2015 & 1.00 & 2.1255 & 0.3006 & 23.5100 & 0.5965 \\
\hline Niger Insurance & 2016 & 1.00 & 4.2271 & 0.1080 & 9.1450 & 0.6262 \\
\hline Niger Insurance & 2017 & 1.00 & 1.9120 & 0.1701 & 115.4000 & 0.6671 \\
\hline Niger Insurance & 2018 & 0.64 & 2.6512 & 0.1642 & 92.7700 & 0.6269 \\
\hline Prestige & 2007 & 1.44 & 0.6858 & 0.2475 & 2.2220 & 0.2550 \\
\hline Prestige & 2008 & 1.30 & 0.3917 & 0.3297 & 2.3025 & 0.2650 \\
\hline Prestige & 2009 & 0.31 & 0.4617 & 0.4580 & 31.5750 & 0.3739 \\
\hline Prestige & 2010 & 0.71 & 0.7511 & 0.3563 & 12.9050 & 0.3704 \\
\hline Prestige & 2011 & 0.59 & 0.8179 & 0.2329 & 14.5950 & 0.3238 \\
\hline Prestige & 2012 & 0.36 & 2.2178 & 0.3114 & 5.6200 & 0.5999 \\
\hline Prestige & 2013 & 1.05 & 6.4133 & 0.3535 & 20.3850 & 0.5645 \\
\hline Prestige & 2014 & 0.95 & 0.9440 & 0.1127 & 7.2500 & 0.6307 \\
\hline Prestige & 2015 & 0.92 & 3.7576 & 0.1360 & 29.6100 & 0.4396 \\
\hline Prestige & 2016 & 1.00 & 3.5118 & 0.2186 & $37,058.0000$ & 0.3572 \\
\hline Prestige & 2017 & 1.00 & 4.2678 & 0.3402 & 53.8450 & 0.3624 \\
\hline Prestige & 2018 & 1.09 & 5.1700 & 0.1653 & 3.1500 & 0.3778 \\
\hline Standard Allian & 2007 & 2.48 & 0.2762 & 0.2425 & 10.6870 & 0.1421 \\
\hline Standard Allian & 2008 & 0.96 & 2.1514 & 0.1115 & 10.8175 & 0.0469 \\
\hline Standard Allian & 2009 & 0.28 & 1.6057 & 0.1273 & 0.7400 & 0.1232 \\
\hline Standard Allian & 2010 & 0.55 & 1.2464 & 0.3344 & 13.5750 & 0.3373 \\
\hline Standard Allian & 2011 & 0.96 & 1.4221 & 0.4400 & 117.1450 & 0.3613 \\
\hline Standard Allian & 2012 & 1.00 & 1.1475 & 0.5486 & 151.5300 & 0.4545 \\
\hline Standard Allian & 2013 & 1.00 & 1.1251 & 0.2195 & 0.3250 & 0.4564 \\
\hline Standard Allian & 2014 & 1.00 & 0.8048 & 0.3091 & 6.3010 & 0.5574 \\
\hline Standard Allian & 2015 & 1.00 & 0.6965 & 0.1394 & 203.0550 & 0.6100 \\
\hline Standard Allian & 2016 & 1.00 & 0.7666 & 0.0889 & 0.0004 & 0.6429 \\
\hline Standard Allian & 2017 & 1.00 & 0.8390 & 0.2297 & 12.5523 & 0.6171 \\
\hline Standard Allian & 2018 & 0.70 & 0.8977 & 0.1655 & 54.4450 & 0.6031 \\
\hline Sovereign Trust & 2007 & 3.07 & 0.4439 & 0.3659 & 4.3670 & 0.1873 \\
\hline Sovereign Trust & 2008 & 1.11 & 0.4606 & 0.4649 & 64.3460 & 0.3244 \\
\hline Sovereign Trust & 2009 & 0.23 & 1.0575 & 0.4327 & 0.8050 & 0.3476 \\
\hline Sovereign Trust & 2010 & 0.69 & 1.4407 & 0.3046 & 0.7008 & 0.6073 \\
\hline Sovereign Trust & 2011 & 1.00 & 0.6554 & 0.7950 & 0.0195 & 0.6759 \\
\hline Sovereign Trust & 2012 & 1.00 & 0.9940 & 0.8677 & 0.0183 & 0.5587 \\
\hline Sovereign Trust & 2013 & 1.01 & 1.2110 & 0.6011 & 0.5664 & 0.5973 \\
\hline Sovereign Trust & 2014 & 0.99 & 1.2110 & 0.6011 & 0.0005 & 0.5584 \\
\hline Sovereign Trust & 2015 & 1.00 & 1.2050 & 0.5674 & 0.0014 & 0.4576 \\
\hline Sovereign Trust & 2016 & 1.00 & 1.2554 & 0.5837 & 0.0005 & 0.4496 \\
\hline Sovereign Trust & 2017 & 1.00 & 1.3121 & 0.5833 & 0.4158 & 0.4942 \\
\hline Sovereign Trust & 2018 & 0.56 & 1.9938 & 0.5383 & 1.2875 & 0.4859 \\
\hline Unic Diversified & 2007 & 1.48 & 0.5476 & 0.2814 & 38.2940 & 0.3247 \\
\hline Unic Diversified & 2008 & 0.93 & 0.5443 & 0.3318 & 6.2275 & 0.4118 \\
\hline Unic Diversified & 2009 & 0.26 & 1.7478 & 0.2257 & 2.1965 & 0.4999 \\
\hline Unic Diversified & 2010 & 0.72 & 1.8935 & 0.0191 & 11.0300 & 0.5530 \\
\hline Unic Diversified & 2011 & 0.81 & 2.2767 & 0.0204 & 3.6900 & 0.5203 \\
\hline Unic Diversified & 2012 & 1.00 & 2.0920 & 0.0000 & 25.6650 & 0.5378 \\
\hline Unic Diversified & 2013 & 1.00 & 3.5110 & -0.0343 & 0.0019 & 0.6433 \\
\hline
\end{tabular}




\begin{tabular}{|c|c|c|c|c|c|c|}
\hline Firm & Year & STR "N" & $\begin{array}{l}\text { Book-To-Mkt } \\
\text { Ratio }\end{array}$ & $\begin{array}{l}\text { Net Int. Margin } \\
\text { Ratio }\end{array}$ & FSZ "N'M" & LVR Ratio \\
\hline Unic Diversified & 2014 & 1.00 & 3.3865 & -0.4915 & 0.7500 & 0.7616 \\
\hline Unic Diversified & 2015 & 1.00 & 3.3865 & 0.0000 & 3.3800 & 0.7616 \\
\hline Unic Diversified & 2016 & 1.00 & 1.6801 & 0.0020 & 0.0000 & 0.5584 \\
\hline Unic Diversified & 2017 & 1.00 & 2.1781 & 0.0098 & 197.9075 & 0.6062 \\
\hline Unic Diversified & 2018 & 0.50 & 3.7554 & 0.0044 & 31.2250 & 0.6062 \\
\hline Wapic Insurance & 2007 & 1.18 & 0.4026 & 0.1515 & 31.9935 & 0.2654 \\
\hline Wapic Insurance & 2008 & 1.07 & 0.2712 & 0.4720 & 7.9875 & 0.2985 \\
\hline Wapic Insurance & 2009 & 0.25 & 0.7356 & 0.3784 & 17.7660 & 0.2569 \\
\hline Wapic Insurance & 2010 & 0.37 & 1.9549 & 0.2285 & 14.5700 & 0.2570 \\
\hline Wapic Insurance & 2011 & 0.75 & 2.4062 & 0.2433 & 8.7500 & 0.2170 \\
\hline Wapic Insurance & 2012 & 1.06 & 2.8279 & 0.1451 & 7.2550 & 0.2220 \\
\hline Wapic Insurance & 2013 & 1.77 & 1.3087 & 0.3230 & 299.5950 & 0.2608 \\
\hline Wapic Insurance & 2014 & 0.78 & 1.6293 & 1.2000 & 0.0630 & 0.2737 \\
\hline Wapic Insurance & 2015 & 0.65 & 2.1780 & 0.2073 & 34.5700 & 0.2772 \\
\hline Wapic Insurance & 2016 & 0.99 & 2.2467 & 0.1743 & 13.0400 & 0.2700 \\
\hline Wapic Insurance & 2017 & 1.00 & 2.2956 & 0.2168 & 9.2550 & 0.2798 \\
\hline Wapic Insurance & 2018 & 0.97 & 1.7754 & 0.3343 & 45.7450 & 0.3771 \\
\hline Royal Exchange & 2007 & 1.38 & 0.5017 & 0.0949 & 3.8540 & 0.2353 \\
\hline Royal Exchange & 2008 & 1.01 & 3.4219 & -0.0045 & 1.0410 & 5.2394 \\
\hline Royal Exchange & 2009 & 0.39 & 13.0046 & 8.2549 & 0.9105 & 0.2610 \\
\hline Royal Exchange & 2010 & 0.36 & 52.9656 & 0.0742 & 25.5850 & 0.0976 \\
\hline Royal Exchange & 2011 & 0.84 & 19.9694 & 0.2008 & 7.2450 & 0.0993 \\
\hline Royal Exchange & 2012 & 1.00 & 16.0165 & 0.6981 & 68.7300 & 0.1069 \\
\hline Royal Exchange & 2013 & 1.17 & 13.4907 & 0.8204 & 8.2850 & 0.1042 \\
\hline Royal Exchange & 2014 & 0.93 & 15.4373 & 0.7777 & 73.0250 & 0.2336 \\
\hline Royal Exchange & 2015 & 0.91 & 15.2033 & 0.7614 & 2.3350 & 0.2667 \\
\hline Royal Exchange & 2016 & 0.99 & 14.3466 & 0.7712 & 204.5900 & 0.3729 \\
\hline Royal Exchange & 2017 & 1.00 & 13.4147 & 0.7042 & 0.5300 & 0.4978 \\
\hline Royal Exchange & 2018 & 0.56 & 16.2913 & -0.3037 & 2.8750 & 0.6443 \\
\hline Union Homes & 2007 & 1.22 & 0.3123 & 0.0232 & 0.0825 & 0.9233 \\
\hline Union Homes & 2008 & 0.67 & 0.2754 & 0.0362 & 146.0855 & 0.8625 \\
\hline Union Homes & 2009 & 0.23 & 0.5295 & 0.0415 & 21.8035 & 0.8734 \\
\hline Union Homes & 2010 & 0.49 & 6.6354 & 0.0039 & 48.6050 & 0.9984 \\
\hline Union Homes & 2011 & 0.74 & -0.9560 & 0.0562 & 28.8400 & 1.1357 \\
\hline Union Homes & 2012 & 0.82 & -2.7286 & 0.0620 & 0.0060 & 1.2858 \\
\hline Union Homes & 2013 & 1.00 & 48.0727 & 0.5821 & 1.8930 & 1.5651 \\
\hline Union Homes & 2014 & 1.00 & 49.2946 & 0.6207 & 225.1950 & 1.7073 \\
\hline Union Homes & 2015 & 7.64 & 46.8845 & 2.4842 & 272.8400 & 1.6746 \\
\hline Union Homes & 2016 & 0.90 & 66.5042 & 4.8113 & 191.5100 & -0.0443 \\
\hline Union Homes & 2017 & 0.88 & 108.2045 & 4.6832 & 6.7632 & -0.0450 \\
\hline Union Homes & 2018 & 0.12 & 67.8441 & 4.6428 & 33.4429 & -0.1075 \\
\hline Keys: & \multirow{5}{*}{\multicolumn{6}{|c|}{$\begin{array}{l}\text { STR = Stock return } \\
\text { BMR = Book-To-Martket Ratio } \\
\text { NIM = Net Interest Margin Ratio } \\
\text { FSZ = Firm Size } \\
\text { LVR = Leverage }\end{array}$}} \\
\hline & & & & & & \\
\hline & & & & & & \\
\hline & & & & & & \\
\hline & & & & & & \\
\hline
\end{tabular}




\section{APPENDIX B}

- xtsum str bmr nim fsz lvr mpr

\begin{tabular}{|c|c|c|c|c|c|c|c|}
\hline \multicolumn{2}{|c|}{ Variable } & Mean & Std. Dev. & Min & $\operatorname{Max}$ & \multicolumn{2}{|c|}{ Observations } \\
\hline str & overall & 1.040144 & .6827 & .12 & 7.64 & $\mathrm{~N}=$ & 348 \\
\hline & between & & .1184877 & .8783333 & 1.3275 & $\mathrm{n}=$ & 29 \\
\hline & within & & .67267 & -.149023 & 7.370977 & $\mathrm{~T}=$ & 12 \\
\hline \multirow[t]{3}{*}{ bmr } & overall & 2.16968 & 2.755737 & -2.7286 & 19.9694 & $\mathrm{~N}=$ & 348 \\
\hline & between & & 2.05263 & .539525 & 12.19955 & $\mathrm{n}=$ & 29 \\
\hline & within & & 1.874663 & -9.528169 & 13.20721 & $\mathrm{~T}=$ & 12 \\
\hline \multirow[t]{3}{*}{ nim } & overall & .2742552 & .7196694 & -.6692 & 8.2549 & $\mathrm{~N}=$ & 348 \\
\hline & between & & .3638539 & .0307333 & 1.503942 & $\mathrm{n}=$ & 29 \\
\hline & within & & .6242845 & -1.225786 & 7.458355 & $\mathrm{~T}=$ & 12 \\
\hline \multirow[t]{3}{*}{ fsz } & overall & 24.32152 & 8.841858 & 8.04 & 39.12 & $\mathrm{~N}=$ & 348 \\
\hline & between & & 2.345757 & 20.795 & 28.54667 & $\mathrm{n}=$ & 29 \\
\hline & within & & 8.53524 & 7.774856 & 40.68319 & $\mathrm{~T}=$ & 12 \\
\hline \multirow[t]{3}{*}{ lvr } & overall & .5192638 & .1603639 & .2194 & .682 & $\mathrm{~N}=$ & 348 \\
\hline & between & & .032467 & .465 & .5904583 & $\mathrm{n}=$ & 29 \\
\hline & within & & .1571493 & .1803305 & .7362638 & $\mathrm{~T}=$ & 12 \\
\hline \multirow[t]{3}{*}{ mpr } & overall & .109225 & .0247918 & .0608 & .14 & $\mathrm{~N}=$ & 348 \\
\hline & between & & 0 & .109225 & .109225 & $\mathrm{n}=$ & 29 \\
\hline & within & & .0247918 & .0608 & .14 & $\mathrm{~T}=$ & 12 \\
\hline
\end{tabular}

- swilk str bmr nim fsz lvr mpr

Shapiro-Wilk w test for normal data

\begin{tabular}{r|rrrrr} 
Variable & Obs & W & V & z & Prob $>$ z \\
\hline str & 348 & 0.63768 & 88.077 & 10.587 & 0.00000 \\
bmr & 348 & 0.60317 & 96.468 & 10.802 & 0.00000 \\
nim & 348 & 0.33092 & 162.649 & 12.037 & 0.00000 \\
fsz & 348 & 0.97662 & 5.684 & 4.108 & 0.00002 \\
lvr & 348 & 0.81833 & 44.162 & 8.955 & 0.00000 \\
mpr & 348 & 0.94803 & 12.633 & 5.996 & 0.00000
\end{tabular}


- pwcorr str bmr nim fsz lvr mpr, star (0.05) sig

\begin{tabular}{|c|c|c|c|c|c|c|}
\hline & str & bmr & nim & fsz & lvr & mpr \\
\hline str & 1.0000 & & & & & \\
\hline $\mathrm{bmr}$ & $\begin{array}{r}-0.0838 \\
0.1189\end{array}$ & 1.0000 & & & & \\
\hline nim & $\begin{array}{l}0.0582 \\
0.2787\end{array}$ & $\begin{array}{l}0.2918 \text { * } \\
0.0000\end{array}$ & 1.0000 & & & \\
\hline fsz & $\begin{array}{l}0.3735 * \\
0.0000\end{array}$ & $\begin{array}{r}-0.0937 \\
0.0808\end{array}$ & $\begin{array}{r}-0.0245 \\
0.6483\end{array}$ & 1.0000 & & \\
\hline $\operatorname{lvr}$ & $\begin{array}{l}0.2150 * \\
0.0001\end{array}$ & $\begin{array}{l}0.0079 \\
0.8827\end{array}$ & $\begin{array}{l}0.0156 \\
0.7712\end{array}$ & $\begin{array}{c}-0.3285 * \\
0.0000\end{array}$ & 1.0000 & \\
\hline mpr & $\begin{array}{r}-0.0038 \\
0.9442\end{array}$ & $\begin{array}{l}0.1460 * \\
0.0064\end{array}$ & $\begin{array}{r}-0.0302 \\
0.5740\end{array}$ & $\begin{array}{c}-0.1779 \star \\
0.0009\end{array}$ & $\begin{array}{l}0.1645 * \\
0.0021\end{array}$ & 1.0000 \\
\hline
\end{tabular}

- reg str bmr nim fsz lvr mpr

\begin{tabular}{|c|c|c|c|c|c|c|c|}
\hline Source & SS & $d f$ & \multicolumn{2}{|c|}{ MS } & & \multirow{2}{*}{$\begin{array}{l}\text { Number of obs }= \\
\text { F( 5, 342) }= \\
\text { Prob }>F\end{array}$} & \multirow{2}{*}{$\begin{array}{r}=\quad 348 \\
=\quad 26.14 \\
=\quad 0.0000\end{array}$} \\
\hline Model & 148.701265 & 5 & \multicolumn{2}{|c|}{29.7402529} & & & \\
\hline Residual & 389.126483 & 342 & \multicolumn{2}{|c|}{1.13779673} & & \multirow{2}{*}{$\begin{array}{l}\text { R-squared } \\
\text { Adj R-squared } \\
\text { Root MSE }\end{array}$} & $=0.2765$ \\
\hline Total & 537.827748 & 347 & 1.5 & 93587 & & & $=1.0667$ \\
\hline str & Coef. & Std. & Err. & t & $P>|t|$ & [95\% Conf. & Interval] \\
\hline $\mathrm{bmr}$ & -.0318927 & .0220 & 826 & -1.44 & 0.150 & -.0753275 & .0115422 \\
\hline nim & .149345 & .0834 & 651 & 1.79 & 0.074 & -.0148246 & .3135147 \\
\hline fsz & .0700526 & .0069 & 396 & 10.09 & 0.000 & .056403 & .0837022 \\
\hline lvr & 2.884653 & .380 & 599 & 7.57 & 0.000 & 2.135334 & 3.633973 \\
\hline mpr & 1.83659 & 2.39 & 338 & 0.77 & 0.443 & -2.868959 & 6.542138 \\
\hline cons & -1.54801 & .399 & 496 & -3.88 & 0.000 & -2.332911 & -.7631099 \\
\hline
\end{tabular}

- hettest

Breusch-Pagan / Cook-Weisberg test for heteroskedasticity Ho: Constant variance

Variables: fitted values of str

$\operatorname{chi2}(1)=91.28$

Prob $>$ chi2 $=0.0000$ 
- vif

\begin{tabular}{r|cr} 
Variable & VIF & $1 /$ VIF \\
\hline fsz & 1.15 & 0.870928 \\
lvr & 1.14 & 0.878544 \\
bmr & 1.13 & 0.885440 \\
nim & 1.10 & 0.908780 \\
mpr & 1.07 & 0.932125 \\
\hline Mean VIF & 1.12 & \\
. xtreg str bmr nim fsz lvr mpr, fe
\end{tabular}

Fixed-effects (within) regression Group variable: id

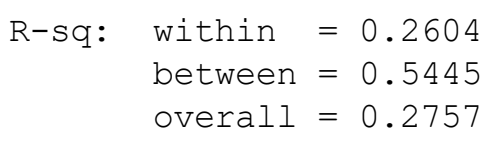

$\operatorname{corr}\left(u_{-} i, \quad \mathrm{Xb}\right)=0.0780$

$\begin{array}{llr}\text { Number of obs } & = & 348 \\ \text { Number of groups } & = & 29 \\ \text { Obs per group: min } & = \\ \text { avg } & = & 12.0 \\ \max & = & 12 \\ & = & 22.12 \\ \text { F }(5,314) & = & 0.0000 \\ \text { Prob }>\text { F } & & \end{array}$

\begin{tabular}{r|rrrrrr}
\hline str & Coef. & Std. Err. & $t$ & P $>$ t l & [95\% Conf. Interval] \\
\hline bmr & -.0433813 & .0328767 & -1.32 & 0.188 & -.1080678 & .0213051 \\
nim & .1645933 & .096028 & 1.71 & 0.088 & -.0243464 & .3535331 \\
fsz & .0666895 & .00733 & 9.10 & 0.000 & .0522674 & .0811116 \\
lvr & 2.81916 & .3969918 & 7.10 & 0.000 & 2.038059 & 3.60026 \\
mpr & 1.892678 & 2.482136 & 0.76 & 0.446 & -2.991044 & 6.776399 \\
_cons & -1.417587 & .4151574 & -3.41 & 0.001 & -2.234429 & -.6007455 \\
\hline sigma_u & .22520162 & & & & & \\
sigma_e & 1.089357 & & & & & \\
rho & .04098527 & (fraction of variance due to u_i) & \\
\hline
\end{tabular}

F test that all u_i=0: $\quad F(28,314)=0.50 \quad$ Prob $>F=0.9860$

- est store fixed 
- xtreg str bmr nim fsz lvr mpr, re

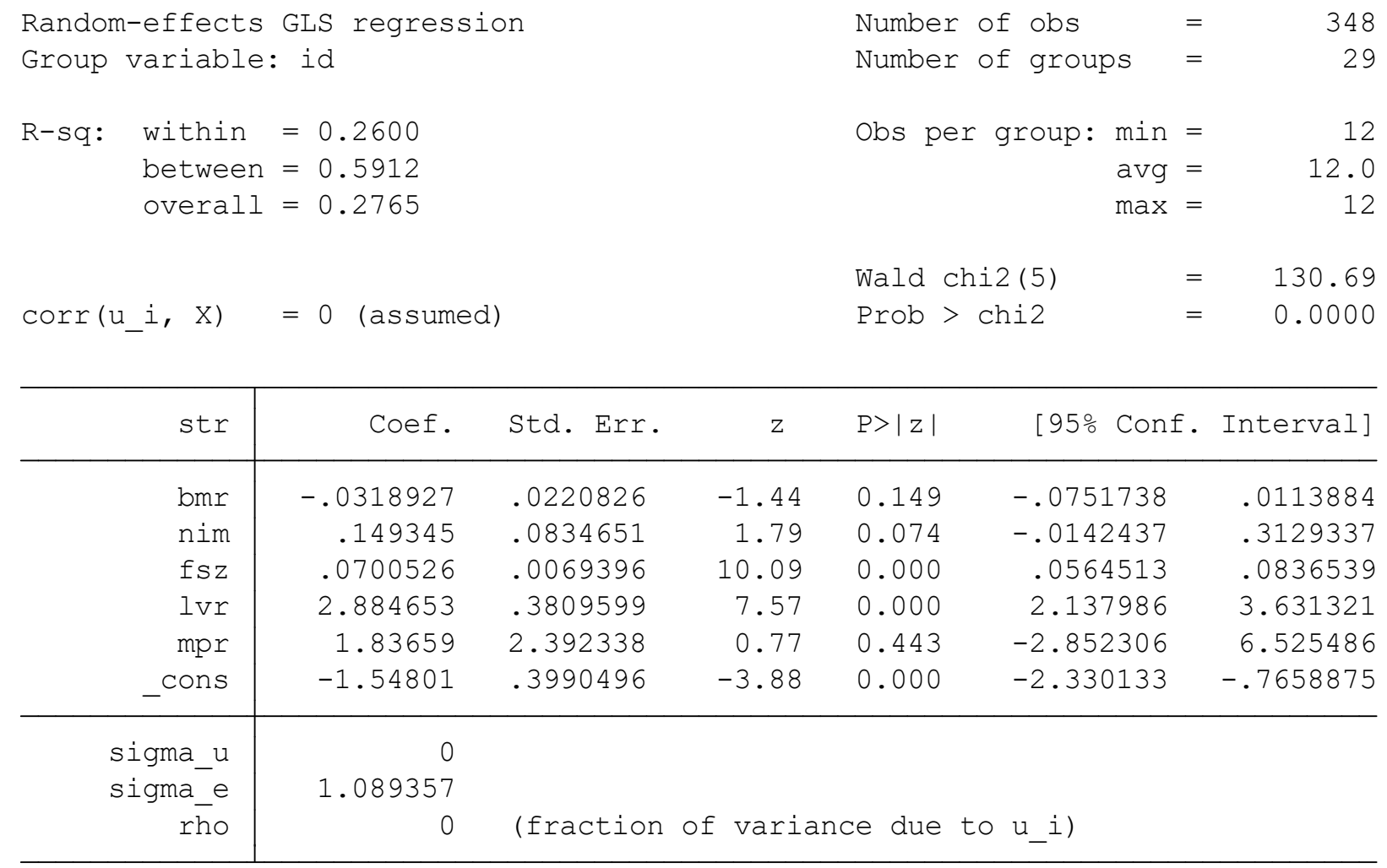

- est store random

- hausman fixed random

\begin{tabular}{|c|c|c|c|c|}
\hline & \multicolumn{2}{|c|}{ - Coefficients - } & \multirow[b]{2}{*}{$\begin{array}{c}(\mathrm{b}-\mathrm{B}) \\
\text { Difference }\end{array}$} & \multirow[b]{2}{*}{$\begin{array}{c}\operatorname{sqrt}\left(\operatorname{diag}\left(V_{-}{ }^{b}-V_{-} B\right)\right. \\
\text { S.E. }\end{array}$} \\
\hline & $\begin{array}{c}\text { (b) } \\
\text { fixed }\end{array}$ & $\begin{array}{c}(\mathrm{B}) \\
\text { random }\end{array}$ & & \\
\hline bmr & -.0433813 & -.0318927 & -.0114887 & .0243564 \\
\hline nim & .1645933 & .149345 & .0152483 & .0474864 \\
\hline fsz & .0666895 & .0700526 & -.0033631 & .0023603 \\
\hline lvr & 2.81916 & 2.884653 & -.0654937 & .1116784 \\
\hline mpr & 1.892678 & 1.83659 & .0560878 & .6616046 \\
\hline
\end{tabular}

$\mathrm{b}=$ consistent under $\mathrm{Ho}$ and $\mathrm{Ha}$; obtained from xtreg $\mathrm{B}=$ inconsistent under $\mathrm{Ha}$, efficient under Ho; obtained from xtreg

Test: Ho: difference in coefficients not systematic

$\begin{aligned} \operatorname{chi2}(5) & = & (\mathrm{b}-\mathrm{B}) \cdot\left[\left(\mathrm{V}_{-} \mathrm{b}_{-}-\mathrm{V}_{-} B\right)^{\wedge}(-1)\right](\mathrm{b}-\mathrm{B}) \\ & = & 2.55 \\ \text { Prob }>\operatorname{chi2} & = & 0.7693\end{aligned}$


- xttesto

Breusch and Pagan Lagrangian multiplier test for random effects

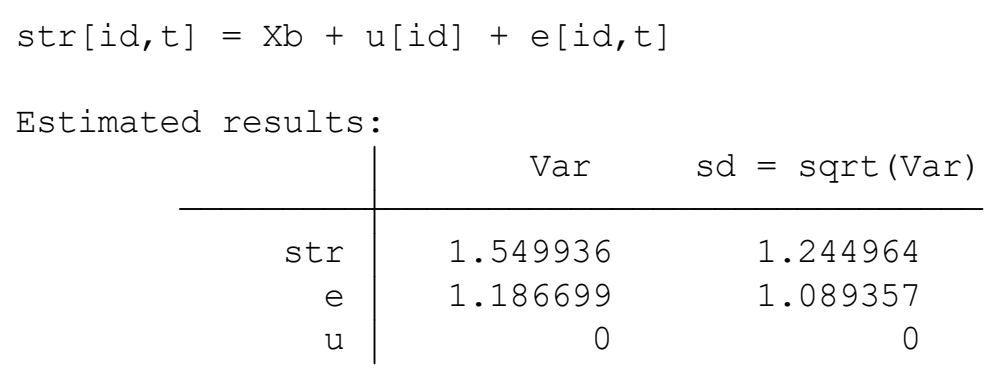

Test: $\quad \operatorname{Var}(u)=0$

$\frac{\text { chibar2 }(01)}{\text { Prob }>\text { chibar2 }}=1.0000$

- reg str bmr nim fsz lvr mpr, robust

Linear regression

$\begin{array}{llr}\text { Number of obs } & = & 348 \\ \text { F 5, 342) } & =27.67 \\ \text { Prob }>\text { F } & =0.0000 \\ \text { R-squared } & =0.2765 \\ \text { Root MSE } & =1.0667\end{array}$

\begin{tabular}{r|rrrrrr}
\hline \multirow{2}{*}{ str } & Coef. & Std. Err. & $t$ & P $>|t|$ & [95\% Conf. Interval] \\
\hline bmr & -.0318927 & .0210842 & -1.51 & 0.131 & -.0733637 & .0095784 \\
nim & .149345 & .0713368 & 2.09 & 0.037 & .0090308 & .2896592 \\
fsz & .0700526 & .007661 & 9.14 & 0.000 & .0549841 & .0851211 \\
lvr & 2.884653 & .2802383 & 10.29 & 0.000 & 2.333446 & 3.435861 \\
mpr & 1.83659 & 2.526457 & 0.73 & 0.468 & -3.132762 & 6.805941 \\
- $\operatorname{cons}$ & -1.54801 & .3688436 & -4.20 & 0.000 & -2.273498 & -.8225229 \\
\hline
\end{tabular}

